This item was submitted to Loughborough's Research Repository by the author.

Items in Figshare are protected by copyright, with all rights reserved, unless otherwise indicated.

\title{
Do cross-border mergers and acquisitions increase short-term market performance? The case of Chinese firms
}

PLEASE CITE THE PUBLISHED VERSION

http://dx.doi.org/10.1016/j.ibusrev.2016.06.006

\section{PUBLISHER}

(C) Elsevier

\section{VERSION}

AM (Accepted Manuscript)

\section{PUBLISHER STATEMENT}

This work is made available according to the conditions of the Creative Commons Attribution-NonCommercialNoDerivatives 4.0 International (CC BY-NC-ND 4.0) licence. Full details of this licence are available at: https://creativecommons.org/licenses/by-nc-nd/4.0/

\section{LICENCE}

CC BY-NC-ND 4.0

\section{REPOSITORY RECORD}

Tao, Fang, Xiaohui Liu, Lan Gao, and Enjun Xia. 2016. "Do Cross-border Mergers and Acquisitions Increase Short-term Market Performance? the Case of Chinese Firms". Loughborough University. https://hdl.handle.net/2134/22374. 
Do cross-border mergers and acquisitions increase short-term market performance? The case of Chinese firms

\author{
Fang Tao ${ }^{\mathrm{a}}$ \\ Xiaohui Liu ${ }^{\mathbf{a}^{*}}$ \\ Lan Gao ${ }^{\mathrm{a}}$

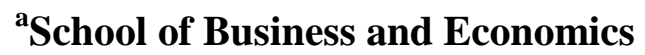 \\ Loughborough University \\ Leicestershire, LE11 3TU \\ Enjun Xia \\ School of Management and Economics \\ Beijing Institute of Technology \\ Beijing 100081, P.R. China \\ Email: enjunxia@bit.edu.cn
}

* Corresponding author. Email: X.liu2@lboro.ac.uk 


\title{
Do cross-border mergers and acquisitions increase short-term market performance? The case of Chinese firms
}

\begin{abstract}
Despite the new momentum in cross-border mergers and acquisitions (M\&As) by emerging market firms, we have a limited understanding of the impact of these activities. Drawing on signalling theory and the institution-based view, this paper examines the extent of stock market reactions to the announcement of cross-border M\&A deals, based on an event study of a sample of Chinese firms during the period 2000-2012. The findings indicate that the announcement of cross-border M\&As results in a positive stock market reaction; this effect is more significant in the mainland Chinese stock markets (Shanghai and Shenzhen) than that in the Hong Kong market. The shareholders of Chinese firms that acquire a target firm in a host country with a low level of political risk gain higher cumulative abnormal returns than those firms targeting companies in countries with a high level of political risk. The shareholders of Chinese state-owned enterprises experience lower abnormal returns compared with those of Chinese privately owned firms when engaging in cross-border M\&A deals.
\end{abstract}

Keywords: Chinese firms, cross-border mergers and acquisitions, stock market reactions, political risk, ownership 


\section{Introduction}

Emerging-economy (EE) firms have increasingly used cross-border mergers and acquisitions (M\&As) as their internationalization strategy in recent years. For example, Chinese firms have been actively involved in cross-border M\&As due to the 'Go Out Policy’ (Chen, 2008) implemented by the Chinese government. The number of completed cross-border M\&As by Chinese firms was only 33 in 2000 and the total value of these deals was \$838.86 million dollars, whereas in 2012 the number of completed deals increased to 146 and their value reached \$22.32 billion dollars (Thomson One Banker, 2013). Chinese firms have attracted attention worldwide with a series of high-profile cross-border M\&As involving well-known western companies, including Lenovo’s acquisition of the Motorola Mobility division (2014) and IBM's PC division (2005), Geely's acquisition of Volvo Corporation (2010), Wanda’s acquisition of Sunseeker (2013) and the AMC Cinema chain (2012), and Huawei’s acquisition of Symantec (2011) and CIP (2012). No wonder that the Economist (2010) noted that 'China buys up the world'.

Despite the rapid pace and increasing importance of cross-border M\&As by Chinese firms, existing research has predominantly focused on M\&As undertaken by firms from developed countries (Ghosh, 2001; Kruse, et al., 2007; Martynova \& Renneboog, 2008; Pazarskis, et al., 2006; Sharma \& Ho, 2002). Only recently have a growing number of studies begun to examine cross-border M\&As by EE firms (Buckley, Elia, \& Kafouros, 2014; Deng \& Yang, 2015; Lebedev, et al., 2015; Ning, et al., 2014; Sun, et al., 2012). Some of these studies (Bhagat, Malhotra, \& Zhu, 2011; Boateng, Wang, \& Yang, 2008; Wang \& Boateng, 2007; Zhou, et al., 2015) found a positive market reaction to cross-border M\&As, while others (Aybar \& Ficici, 2009; Chen \& Young, 2010) found a negative one. The inconsistent findings of the existing studies suggest that stock market reactions to cross-border M\&As by Chinese firms need further academic scrutiny. 
In addition, existing research has tended to assume that there are the same market reactions across stock markets in mainland China and Hong Kong. However, under the formula of 'one country, two systems' (China.org.cn, 2008), the Hong Kong stock market is different from those of mainland China. This leads to a 'one country, two markets' scenario, thus demonstrating the unique institutional setting of China's stock markets. The different institutional arrangements (e.g. ownership restrictions, currency control and liquidity restrictions) between the two markets within one country may trigger different market reactions to the announcement of cross-border M\&As by Chinese firms. This unique 'one country, two markets' scenario remains underexplored in the domain of cross-border M\&As.

Furthermore, there is a lack of comprehensive studies to investigate whether the level of political risk in target countries, and the ownership status of acquiring firms, spur different market reactions to cross-border M\&A deals. The stock market is sensitive to any political risk associated with cross-border M\&As, which is considered as an important signal, especially in emerging economies (Chan \& Wei, 1996; Kim \& Mei, 2001; Wang, Liu, \& Wang, 2004). However, existing studies tend to focus on the impact of geographic and cultural distance on cross-border M\&As (Chakrabarti \& Mitchell, 2013; Ragozzino, 2009) without explicitly taking political risk into account. A recent study by Harzing \& Pudelko (2016) has shown that cultural distance is often used as a proxy for political risk and government restrictions in a host country, and calls for more studies that use more appropriate and accurate constructs to measure host country characteristics, such as political risk. In addition to political risk, we have a limited understanding of how the ownership status of Chinese acquiring firms affects investors’ perception, and hence stock market reactions.

To remedy these research gaps, we examine the following research questions. What are the stock market reactions to cross-border M\&A announcements by Chinese firms? Do investors in the Hong Kong stock market respond differently to cross-border M\&As by Chinese firms compared 
with those in the Shanghai and Shenzhen stock markets in mainland China? To what extent does political risk in the country of origin of the target firms, and the ownership status of the acquiring firms, affect the short-term stock market performance of Chinese firms with cross-border M\&As?

To address these research questions, we build our study on signalling theory and the institution-based view to propose that the short-term market performance of Chinese acquiring firms is influenced by a variety of factors including the different institutional settings within China, the political risk of target countries and the ownership status of the acquiring firms. Signalling theory is used to underpin stock market reactions to cross-border M\&As while the institution-based view is adopted to reveal what is behind investors' perceptions in stock markets. In contrast to existing studies which investigate the direct relationship between cross-border M\&As and firm performance, this paper intends to capture stock market reactions based on signalling theory, and unpack how stock markets react to cross-border M\&As by Chinese listed firms. More specifically, we aim to reveal the extent of market reactions to the institutional characteristics associated with cross-border M\&A deals by Chinese listed firms using an event-study method.

Examining the impact of Chinese firms' cross-border M\&As in a systematic manner is timely and enables us to make a number of contributions to the literature on cross-border M\&As in general and EE firms in particular. First, by integrating signalling theory with the institution-based view, this study helps to deepen our understanding of key institutional factors affecting stock market reactions to cross-border M\&A activities by EE firms. Second, the findings from this research will provide new insights into different market reactions to the same cross-border M\&A events within one country with two markets. Our study is one of the first to investigate the extent to which the impact of cross-border M\&As is contingent on the degree of capital market development. Finally, by examining the impact of political risk in host countries and the ownership status of acquiring firms on the short-term market performance of cross-border M\&As, our study 
captures the extent to which different institutional dimensions, such as political risk and ownership status, influence the market reactions of such activities. The findings enrich our understanding of the performance implications of cross-border M\&As by Chinese firms by delineating under what conditions cross-border M\&As create value for Chinese acquirers.

The paper is organised as follows: in Section 2, a number of hypotheses are developed based on the signalling theory and institution-based views. We describe the sample and methodology used in the study in Section 3. The results are discussed in Section 4, while Section 5 discusses findings and their implications, followed by the conclusions.

\section{Theory and hypotheses}

A cross-border M\&A could be interpreted as an indication of a substantial change in a firm's corporate strategy. Stock market investors will react to this change through buying or selling stocks according to their perception of the firm's future performance, which constitutes the stock market reaction. The terms 'stock market reaction' and 'investors' reactions' are interchangeable. Existing research on stock market reactions to cross-border M\&As is summarized in Table 1 and can be classified into two broad categories according the country of origin of the acquiring firms developed countries or emerging economies.

Considerable research has been devoted to the impact of cross-border M\&As on the short-term shareholder values of acquiring firms from developed countries (Asquith, 1983; Faccio, McConnell, \& Stolin, 2006; Firth, 1980; Masulis, Wang, \& Xie, 2007; Mitchell \& Stafford, 2000; Schwert, 2000). However, the empirical evidence is mixed. For example, the extant studies conducted by Asquith (1983), Morck et al. (1990), Lang et al. (1991), Schwert (2000), Floreani and Rigamonti (2001), Moeller et al. (2005), Faccio et al. (2006) and Masulis et al. (2007) found positive abnormal returns for the shareholders of U.S. acquiring firms. In contrast, Langetieg 
(1978) provided a contrary view, indicating that U.S. acquiring firms earn significant negative abnormal returns over the six months before and the twelve months after the merger date, which are similar to those reported in more recent studies (Mitchell \& Stafford, 2000; Sudarsanam, Holl, \& Salami, 1996; Walker, 2000). Bruner (2002) suggested that in the aggregate, abnormal returns to shareholders of U.S. acquiring firms are essentially zero.

Positive abnormal returns have been reported for other developed markets, such as Japan (Kang, Shivdasani, \& Yamada, 2000; Pettway \& Yamada, 1986), Canada (Eckbo \& Thorburn, 2009) and several European countries (Faccio, McConnell, \& Stolin, 2006; Goergen \& Renneboog, 2004; Martynova \& Renneboog, 2008). For example, Ben-Amar and Andre (2006) using a sample of Canadian mergers and acquisitions provided evidence that shareholders of acquiring firms earned positive returns between the periods 1998-2000. On the contrary, Sudarsanam and Mahate (2003) examined a sample of 519 UK acquirers over the period 1983 to 1995 and found negative abnormal returns relative to the month of the merger announcement, with only a third of acquirers experiencing wealth gains. Campa and Hernando (2004) also showed negative cumulative abnormal returns for acquiring firms involving cross-border M\&As.

Despite the increasing number of cross-border M\&As by EE firms, limited studies have examined the impact of cross-border M\&As by these firms. Zhu and Malhotra (2008) find evidence of positive gains for the short-term shareholders of Indian acquiring firms. Likewise, using a sample of 425 cross-border acquisitions by Indian firms, Gubbi et al. (2010) show that the shareholders of acquiring firms earned positive abnormal returns from 2000 to 2007. A similar study of 8 emerging countries by Bhagat et al. (2011) based on a sample 678 firms over the 1991-2008 period reports that cross-border M\&As earn positive returns for acquiring firms. However, Aybar and Ficici (2009) examine 433 cross-border acquisitions associated with 58 emerging-market multinationals between the years 1991-2004 and show that shareholders of 
acquiring firms earn negative abnormal returns.

Insert Table 1 near here

Our review of the literature shows that existing studies have either focused on a direct link between M\&A deals and stock market reactions without providing a theoretical underpinning for such reactions (Ben-Amar \& Andre, 2006; Faccio, McConnell, \& Stolin, 2006; Floreani \& Rigamonti, 2001; Gubbi, et al., 2010), or adopted the resource-based view (Gubbi, et al., 2010; Ning, et al., 2014) and agency theory (Chen \& Young, 2010) to examine the impact of internal factors on stock market performance. Although a few studies have considered the impact of geographic distance (Chakrabarti \& Mitchell, 2013; Ragozzino, 2009) and cultural distance (Nicholson \& Salaber, 2013) on cross-border M\&As, which were used to proxy political risk in host countries (Harzing \& Pudelko, 2016). This constrains our understanding of how stock markets react to the political risk associated with cross-border M\&As. Departing from existing research, we combine signalling theory and the institution-based view to capture market reactions to cross-border M\&As by Chinese firms by taking account of the impact of various institutional factors.

Signalling theory is based on the assumption that information is not equally available to all parties at the same time and the theory is fundamentally concerned with reducing information asymmetry between different parties (Spence, 2002). This theory helps to explain how decision-makers interpret and respond to situations where information is both incomplete and asymmetrically distributed among parties (Spence, 1973; 1974). It includes three primary elements: signallers, receivers and the signal itself. Signallers are insiders (e.g. managers or executives) who obtain information about individuals (Spence, 1973) and products (Kirmani \& Rao, 2000) and organizations (Ross, 1977). This information is not available to outsiders. 
Receivers are outsiders who lack information about the organization but would like to receive this information. Due to information asymmetries, outsiders (e.g. investors) cannot obtain adequate information to accurately assess a firm’s true value.

Signalling theory is built on the premise that an internal party, such as an acquirer, possesses special information while external parties, such as investors, may not be able to access such information and may need to rely on other information (Arrow, 1968; 1973; 1959; Arrow \& Debreu, 1954; Grossman \& Hart, 1981; Nelson, 1970). This theory has been used in a variety of management literatures, including strategic management (Ozmel, Reuer, \& Gulati, 2013; Priem, Li, \& Carr, 2012; Reuer \& Ragozzino, 2012), entrepreneurship (Ahlers, et al., 2015; Bergh, et al., 2014; Moss, Neubaum, \& Meyskens, 2015), and human resource management (Lourenço, et al., 2014; Renwick, Redman, \& Maguire, 2012).

We adopt signalling theory to predict how investors would react to the announcement of cross-border M\&As through buying and selling shares in the stock market. The announcement of cross-border M\&As serves as a signal sent by acquiring firms and can influence the expectations of investors. If there is strong confidence in the management of the acquiring firm, and the information about the M\&A transaction is explicit, it should be reflected in the stock market reaction. If the announcement of a cross-border M\&A is interpreted by investors as an optimistic belief in the future, this should cause an increase in the stock price. It is also true where the announcement of cross-border M\&As is perceived negatively by investors, resulting in an decrease in stock prices.

While signalling theory can help capture stock market reactions to cross-border M\&A deals, it is insufficient to reveal what is behind such reactions toward such M\&A deals. Therefore, we integrate the signalling theory with the institution-based view to unpack stock market reactions. The institutional perspective has emerged as an important paradigm, and posits that institutions in a 
society influence firm strategy and performance (Buckley, et al., 2007; North, 1990; Peng, Wang, \& Jiang, 2008). North (1990) defines institutions as the 'rule of the game' in a society. Similarly, Scott (1995) specified that institutions are 'regulative, normative and cognitive structures and activities that provide stability and meaning to social behaviour'. Institutions have long been identified as a key factor affecting cross-border M\&A performance (Peng, Wang, \& Jiang, 2008; Wan \& Hoskisson, 2003), given that cross-border M\&A activities are subject to institutional constraints. Home and host-country institutions exert significant influence on the completion rates of cross-border M\&A deals, and affect the integration and success of post cross-border M\&As (Gubbi, et al., 2010; Zhang, Zhou, \& Ebbers, 2011).

The institution-based view as a widely adopted theoretical lens in IB research is also implicitly reflected in Dunning's OLI paradigm. In more recent studies, Dunning and Lundan (2008) and Cantwell, Dunning and Lundan (2010) have explicitly proposed that institutional factors affecting both the determinants and the outcomes of MNE activity can be incorporated into the OLI paradigm. Building on the analysis of North (1990), Dunning and Lundan (2008) show the direct link between host-country institutional environments and the location-based (L) advantages in the OLI paradigm. The institutionally related location advantages differ between developed and developing countries. Specifically, well-established institutions help firms to reduce uncertainty and risk, and facilitate knowledge acquisition (Lu, et al., 2014; Schwens, Eiche, \& Kabst, 2011; Uhlenbruck, et al., 2006). The host country government can enhance its country's location advantages by improving its institutions in order to attract foreign firms (Guler \& Guillen, 2010; Witt \& Lewin, 2007). Thus, the institutional environment in a host country has important implications for MNEs' internationalization outcomes (Chung \& Beamish, 2005; Cui \& Jiang, 2012; Gao, Liu, \& Lioliou, 2015; Holmes, et al., 2013; Kostova, Roth, \& Dacin, 2008; Pangarkar \& Lim, 2003; Wang, et al., 2012). 
In the case of cross-border M\&As, when assessing a firm’s value and evaluating its future performance to make investment decisions, investors perceive institutional information as an important signal, especially when they are unable to obtain adequate firm-specific information due to information asymmetries. The difference in regulations on financial markets may lead to different market reactions to the same M\&A events. Thus, we expect that market reactions to cross-border M\&A events in the Hong Kong stock market may differ from those in mainland Chinese stock markets. Moreover, when Chinese firms acquire firms from countries with different levels of political risk, which constitutes a major aspect of the institutional environment, stock market investors will interpret and respond to such cross-border M\&As differently. Firms with different ownership status, such as SOEs or privately owned firms, may also generate different stock market reactions, resulting in different performance, given that SOEs can be perceived as a major element of Chinese economic institutions.

\subsection{Market reactions}

The announcement of cross-border M\&As by Chinese firms may release a strong signal to the market according to signalling theory. However, cross-border M\&As are still a newly emerging activity for Chinese firms and Chinese investors. As a result, many Chinese firms involved in cross-border M\&As are 'first-time buyers’ who have not been involved in any cross-border M\&As

previously. Cross-border M\&As by Chinese firms are typically interpreted as a very strong signal released by the top management of Chinese acquirers, indicating their ambitions and confidence in the global market (Gubbi, et al., 2010). Thus, the announcement of cross-border M\&As by Chinese firms is likely to be perceived positively by stock market investors.

In addition, the announcement of cross-border M\&As by Chinese firms may indicate Chinese firms' engagement in seeking strategic assets in order to enhance their performance and 
catch up with global giants (Deng, 2007). M\&As are used as an important approach through which Chinese firms obtain resources and capabilities that are not available in the domestic market (Deng, 2007; Rui \& Yip, 2008). These resources, including natural resources, patent-protected technologies, well-known brands, as well as superior managerial and marketing skills (Athreye \& Kapur, 2009; Chen, 2008; Rui \& Yip, 2008), can be converted into competitive advantages in the post-acquisition period. Thus, investors may perceive that cross-border M\&As serve as a strategic means of addressing resource and capability deficits, and overcoming domestic market constraints. Moreover, firms can better exploit their existing resources and competitive advantages in new markets to realize economies of scale ( $\mathrm{Li}, \mathrm{Li}, \&$ Wang, 2016). Therefore, cross-border M\&As will be perceived to enhance the competitive advantages of Chinese firms by integrating the acquired resources and capabilities from overseas. Ultimately, investors will expect cross-border M\&As to create shareholder value due to improved competitive advantage and firm performance.

Finally, the Chinese government has promoted and encouraged Chinese firms to invest abroad with the 'go abroad' policy since 1999 (Luo, Xue, \& Han, 2010). The support from the Chinese government in the form of tax deductions, low-interest loans and investment treaties with other governments has helped Chinese companies to deal with host-country governments and institutions (Luo, Xue, \& Han, 2010). The Chinese government's political and financial support is interpreted as a positive signal and thus leads to a positive market reaction.

It should be noted that cross-border M\&A announcements may negatively affect the market and hence lead to a decrease in stock prices (Aybar \& Ficici, 2009). However, growing fast and being big has become a widely accepted strategy among Chinese firms and this strategy is supported by the Chinese government (Chen \& Shih, 2008). In this regard, Chinese firms are likely to create positive market expectations due to the potential benefits associated with cross-border M\&A deals. Hence, cross-border M\&As are more likely to generate positive stock market 
reactions in China (Gaur, Delios, \& Singh, 2007).

In summary, for Chinese firms, cross-border M\&As generally represent a unique and important strategic means of value creation, given that these activities enable Chinese firms to obtain critical resources and capabilities and help them overcome domestic institutional constraints in developing these critical resources, thus raising their profile in the eye of investors. These firms are likely to create positive market expectations due to various benefits associated with cross-border M\&A deals. This can result in positive stock market reactions in general which in turn affect the market performance of those firms involved in cross-border M\&A activities. Therefore, we propose:

Hypothesis 1a: The announcement of cross-border M\&As by Chinese firms results in a positive stock market reaction.

While we hypothesise that cross-border M\&As by Chinese firms will generate positive market reactions, we also need to differentiate market reactions in mainland Chinese stock markets with the Hong Kong stock market, given the unique institutional settings of 'one country, two systems'. There may be asymmetric market reactions to the same news in the two types of stock markets across China. The different market reactions in stock markets across China can be shown in the stock market prices and the magnitude of future volatility of return.

Under the formula 'one country, two systems', the Hong Kong stock market is significantly different from the Shanghai and Shenzhen stock market in mainland China. Good-news-chasing behaviour by investors has been observed in mainland China, but to a lesser degree in the Hong Kong stock market and stock markets in the developed world (Wang, Liu, \& Wang, 2004). This good-news-chasing behaviour means that the impact of good news (positive unexpected shock) on future volatility is larger than that of bad news (negative unexpected shock) of the same magnitude 
(Yeh \& Lee, 2000) and could lead to different market reactions to cross-border M\&A activities by Chinese firms. The good-news-chasing behaviour of investors in mainland China could be explained by the unique institutional features of stock markets in China. In mainland China, the liquidity of shares traded in the Shanghai and Shenzhen stock markets is limited compared to those in the Hong Kong market, due to significant constraints on the tradability of state shares and legal-person shares (Yeung \& Huang, 2014). Given the huge amount of 'hot' money flowing around the mainland China stock markets, limited liquidity of share trading will aggregate the market reactions to the announcement of cross-border M\&As.

Furthermore, there is a lack of institutional investors, especially experienced international institutional investors in the Shanghai and Shenzhen stock markets due to institutional restrictions. Most shares traded in the Shanghai and Shenzhen stock markets are domestic shares that are generally restricted to domestic investors (Wang \& Jiang, 2004). Foreign investment is only allowed through a tightly-regulated structure known as the Qualified Foreign Institutional Investor (QFII) System. In mainland China, the turnover is overwhelmingly a result of actions by individual domestic retail investors. According to the Shanghai Stock Exchange Statistical Yearbook (2014), the retail investors in this market contributed $82.24 \%$ of total market turnover value which is considerably higher than the Hong Kong stock market (only 25\%). A huge number of retail investors in the mainland Chinese stock markets, called 'noise traders', are relatively inexperienced in trading and they may respond more positively than others to the announcement of cross-border M\&As because they have no access to inside information and so they can, at times, behave irrationally (Black, 1986). Driven by the lack of other investment options in less-established Chinese capital markets, and institutional restrictions, retail investors in mainland China are more proactive in the stock markets than those in any other main stock markets. Those irrationally optimistic retail investors in mainland China may react differently from experienced 
overseas institutional investors in the Hong Kong stock market to the announcement of cross-border M\&As. Accordingly, we proposed that:

Hypothesis 1b: The positive stock market reaction is stronger in the mainland Chinese stock markets than in the Hong Kong stock market.

In discussing the market reactions to cross-border M\&As by Chinese firms, we further consider the extent to which the stock market performance of M\&As is influenced by institutional characteristics associated with cross-border M\&As. Specifically, we assess the extent of market reactions to political risks in target firms' country of origin and the ownership status of acquiring firms. In doing so, we aim to capture the political dimension of the institutional environment of target firms’ country of origin, and different types of acquiring firms.

\subsection{Political Risk: stability and governance quality}

Political risk constitutes an important aspect of institutional environments and is closely connected to the way institutions function in a country (Bilson, Brailsford, \& Hooper, 2002). It refers to the degree of political stability within a country, the quality of the laws, regulations, administrative procedures and policies formally sanctioned by the government (Cuervo-Cazurra, 2006; 2008; Delios \& Henisz, 2003). Host countries with different levels of political risk may have different performance implications with regard to cross-border M\&As, which in turn can affect market reactions. In this study, we mainly consider two important dimensions of political risk, namely political stability and governance quality.

\section{Political Stability}

There are a number of reasons why the political stability of a target firm’s country of origin can affect market reactions to cross-border M\&As. Firstly, the level of political stability may affect 
investors’ risk perception, and thus lead to different market reactions (Bekaert, et al., 2014; Pástor \& Veronesi, 2013; 2012). Since institutions are developed to create order and stable environments, and so promote economic exchange and cooperation (North, 1990; Williamson, 1985), host countries with high political stability imply low uncertainty and pose low risk to business activities. On the contrary, host countries with low political stability pose a serious challenge to the success of cross-border M\&As (Cao \& Liu, 2013). Foreign firms in particular can be more vulnerable targets during conflict due to their status of being outsiders (Hutchison \& Gibler, 2007). For example, Chinese firms have heavily invested Africa, the Middle East and Latin America in recent years, but civil wars and regional conflicts due to political instability represent big threats to the safety of investment in these regions. In particular, the Libyan civil war in 2011 caused over $\$ 18$ billion dollars of loss to 75 Chinese firms (New.cn, 2011). This implies that the stock market may react negatively to cross-border M\&As if companies seek to acquire firms in countries with a high level of political instability since they may suffer heavy loss in the future.

Secondly, uncertainty associated with sudden policy changes poses further challenges to firms (Bekaert, et al., 2014; Pástor \& Veronesi, 2013; 2012). It is evident that Chinese firms have encountered U-turns in governmental policy towards foreign investments in some African countries when there has been a change of regime (Gao, Liu, \& Lioliou, 2015). Therefore, future M\&As in similar countries may send out negative signals to investors due to the uncertainty.

Thirdly, a low level of political stability is likely to have an impact on post-acquisition activities and hinder the acquirer's efforts to establish and enforce cooperative agreements with local partners (Brouthers \& Hennart, 2007; Feinberg \& Gupta, 2009), thus leading to higher transaction costs when the company tries to acquire and integrate local resources. With uncertainty and high transaction costs, the acquired companies may find it hard to generate positive financial returns to pay dividends or create shareholder value, which will in turn be perceived as a negative 
signal by the stock market. Therefore, we propose:

Hypothesis 2a: The shareholders of Chinese firms that have acquired firms from countries with a high level of political stability gain higher cumulative abnormal returns than those that have acquired firms from countries with a low level of political stability.

\section{Governance quality}

The governance quality of the host country government and its agencies plays an essential role in the success of MNEs’ operations in such countries (Bekaert, et al., 2014; Berry, 2006; Pástor \& Veronesi, 2013). Specifically, well-established rules and regulations help Chinese MNEs reduce the regulatory ambiguity associated with cross-border investments (Gao, Liu, \& Lioliou, 2015). Thus, acquiring firms are able to reduce information search costs and shorten the learning curve associated with foreign operations when investing in countries with clear rules and regulations (Uhlenbruck, et al., 2006). Consequently, firms can devote their time and resources to post-acquisition integration and improved performance.

In addition, the level of bribery and corruption in the host country government can also have an impact on firms investing in these countries. Corrupt practices in host countries where target companies originate not only represent legal and reputational risks, but also influence the financial viability of cross-border M\&A deals (Uhlenbruck, et al., 2006). If a target company derives a proportion of its revenues through corrupt means, this can have a significant impact on the future cash flow of the firm when the acquiring company puts a stop to such corrupt practices (Clifford, 2012). Therefore, M\&A deals in countries with a high level of corruption may send out negative signals to investors.

Furthermore, advanced knowledge and resources are more likely to be learned and obtained from developed countries with a higher level of governance quality where more institutional 
protection is provided for foreign direct investment (Berry, 2006). It is widely recognized that Chinese firms tend to seek high quality knowledge and resources through cross-border M\&As, which has been identified as one of the two motivations of Chinese M\&A deals alongside knowledge exploitation (Deng, 2007; Wang \& Boateng, 2007; Zheng, et al., 2016). Chinese MNEs that lack modern managerial expertise, international market knowledge and advanced technology may be able to acquire valuable knowledge and resources when target firms are from institutionally developed countries because these countries are more likely to possess strategic resources needed by Chinese firms (Nicholson \& Salaber, 2013). Chinese firms can obtain advanced knowledge and resources by acquiring target companies from developed countries with high governance quality and low political risk (Cui, Meryer, \& Hu, 2014; Liu, et al., 2016). Combining these acquired strategic resources, including technological knowledge, market knowledge and managerial knowledge, with low-cost advantage, Chinese firms are able to gain a unique, competitive advantage in both international markets and over their competitors in China who are unable to obtain the same knowledge and resources in the domestic market, thus boosting firm performance (Deng, 2010). Accordingly, we proposed that:

Hypothesis 2b: The shareholders of Chinese firms that have acquired firms from countries with a high level of governance quality gain higher cumulative abnormal returns than those that have acquired firms from countries with a low level of governance quality.

\subsection{Ownership: SOE acquirer vs. private acquirers}

Firms with different ownership status are associated with different capabilities and behave differently, depending on different institutional constraints and competitive pressures (Zhou \& Witteloostuijn, 2010). Research suggests that SOEs not only represent an ownership structure or a form of corporate governance, but are also products of the institutional environment (Bruton, et al., 
2015; Child \& Rodrigues, 2005; Peng, 2000). This is particularly true in China where SOEs are an important instrument used by the government to control and coordinate economic activities (Bai, Lu, \& Tao, 2006; Sun, Tong, \& Tong, 2002; Tian \& Estrin, 2008). This implies that SOEs can be perceived as a major element of economic institutions. Therefore, the ownership status of acquiring firms can affect the market performance of cross-border M\&As by signalling different performance implications.

First, Chinese SOEs obtain preferential treatment from the government and a favourable allocation of resources, which in turn improve the value of the companies (Blanchard \& Shleifer, 2001; Sun \& Tong, 2003; Tian \& Estrin, 2008). Therefore, the success of these companies often depends on their monopoly positions in the domestic market, rather than their management capability or advanced technology (Wu \& Xie, 2010; Zhang, Zhou, \& Ebbers, 2011). Their performance may be adversely affected when SOEs are moving from the Chinese domestic market to the international market (Lin, 2010). It is argued that cross-border M\&As could lead to a lower performance of SOEs due to the weak corporate governance associated with state ownership, as well as possible political interference (Ning, et al., 2014).

Unlike SOEs with a monopoly of government-controlled resources, private firms have to compete based on their technological and marketing capabilities in order to survive and prosper (Peng, 2001). Moreover, private firms tend to be more effective than SOEs in terms of market orientation and innovation (Peng, Wang, \& Tong, 2004). In addition, many private firms have greater flexibility and autonomy in terms of management and decision making. This implies that private firms may be able to compete in foreign markets and integrate target firms more effectively than SOEs, thus leading to a higher level of performance (Liu, et al., 2016).

Moreover, existing research indicates that most SOEs are more interested in utilities and infrastructure industries, such as energy, telecommunication and transport (OECD, 2008). 
However, this may raise political and public concern in the host countries which they target, especially in developed countries (Cui \& Jiang, 2012; Gao, Liu, \& Lioliou, 2015). The natural association between state ownership and the Chinese government may increase political sensitiveness and public concern (Globerman \& Shapiro, 2009; Zhang, Zhou, \& Ebbers, 2011), which may lead to a negative impact on the market performance of SOE acquirers due to possible political interference. Therefore, the announcement of cross-border M\&A deals by firms with different ownership statuses may send different signals to investors, which may result in different stock market reactions and post-acquisition performance. Hence, we propose

Hypothesis 3: The shareholders of Chinese SOE acquirers have lower cumulative abnormal returns from cross-border M\&A deals than those of Chinese private acquirers.

\section{Data and Methodology}

\subsection{Sample and Data Collection}

The data on cross-border M\&As by Chinese firms from January 2000 to December 2012 was obtained from the Thomason One Banker database. Due to the implementation of the 'Go Global' policy initiated in 1999 by the Chinese government, and China's entry into the World Trade Organization (WTO) in 2001, large-scale cross-border M\&As by Chinese firms started from 2000 and this is why the year 2000 has been selected as a starting point of our investigation. For M\&A deals, the Thomson One Banker provides a comprehensive database for global mergers and acquisitions which is widely used for academic research. In this study, all M\&A deal-related data has been sourced from this database, including the announcement date, the name of both acquirers and target firms, as well as the home country of these firms. A Chinese acquiring firm should meet all the following criteria in order to be included in the sample: (i) the M\&A deals are listed as 
completed transitions; (ii) the firm has stock price data which is available on the Shanghai, Shenzhen or Hong Kong stock exchanges; (iii) the announcement date of M\&A lies between January 1, 2000 and December 31, 2012; and (iv) the target companies lie outside mainland China. The final usable sample consists of 165 cross-border M\&As by Chinese acquiring firms.

Table 2 provides an overview of the sample distribution in terms of the industry classification and ownership status of the acquiring firms, as well as the country of origin of foreign target firms. Most Chinese acquirers locate in the manufacturing industry (SIC 20-39) followed by the financial sector (SIC 60-67), which accounts for $58.79 \%$ and $12.12 \%$ of the total cross-border M\&As respectively. For Chinese acquirers, Asia/Pacific firms were most frequently the target of cross-border acquisitions, and account for $49.09 \%$ of total cross-border M\&As, followed by 23.03\% of acquisitions in North America and 20.61\% in Europe. In addition, 58.18\% of cross-border M\&A deals were conducted by Chinese privately owned firms.

Insert Table 2 near here

\subsection{Methodology}

\section{Measurements}

We adopt the notion that stock market reactions to the announcement of cross-border M\&As are reflected in the change of a listed firm's share price around the occurrence of the event (Gaur, Malhotra, \& Zhu, 2013; Gubbi, et al., 2010) and thus the daily stock prices for acquiring ÿrms around the announcement dates are used to measure the stock market performance of these firms. This measure has been widely used in international business and strategic management studies of M\&As (Doukas \& Travlos, 1998; Haleblian \& Finkelstein, 1999; Moeller \& Schlingemann, 2005). More specifically, we use cumulative abnormal returns (CARs) to shareholders as a measure of short-term stock market performance. A company is classified as a 
SOE if the government has a majority ownership share.

Following previous studies (Gubbi, et al., 2010), we use the World Governance Indicators (WGI) complied by Kaufman et al. (2010) to measure political risk. The WGI index constructs aggregate indicators of six dimensions of governance for 215 countries and territories from 1996 to 2012. These six items include voice and accountability (VA), political stability and absence of violence (PS), government effectiveness (GE), regulatory quality (RQ), rule of law (RL), and control of corruption (CC). We use the first two items to measure political stability and the rest to measure governance quality. Each of these six items has values that range from -2.5 to 2.5, with higher values reflecting lower political risk in the country of origin of respective target firms. Values $\geqslant 0$ reflect lower levels of political risk, whereas those $<0$ indicate higher levels of such risk.

\section{Event study}

In order to investigate the impact of Chinese cross-border M\&As on the stock-market performance of acquiring firms, the event study method is employed to calculate and analyse cumulative abnormal returns (Aybar \& Ficici, 2009; Chari, Ouimet, \& Tesar, 2010). This method is based on the assumption of immediate information processing by stock market participants (Fama, 1991) and can be used to determine whether there is an abnormal effect on stock prices associated with unanticipated events, such as M\&As.

Prior studies using the event study method indicate that investors use information about a firm’s cross-border M\&As to adjust expectations about its performance potential, as evidenced by changes in cumulative abnormal returns (CARs) upon the announcement of cross-border M\&As. The event study method is widely used to capture market reactions to an announced event that was previously unexpected (McWilliams \& Siegel, 1997). 
In order to assess the stock price reaction to announcements of cross-border of M\&As, abnormal return (AR) is calculated based on a standard market model (Brown \& Warner, 1985) which can be presented in the following equation.

$A R_{i t}=R_{i t}-\left(\alpha_{i}+\beta_{i} R_{m t}\right)$

where $A R_{i t}$ is the abnormal return, $R_{i t}$ is the actual daily stock return for firm ${ }^{i}$ on day $t$, and $R_{m t}$ is the daily return from the Shanghai Stock Exchange Composite Index and Shenzhen Stock Exchange Composite Index and Hong Kong HangSheng Index on day ${ }^{t}$. The coefficients $\alpha_{i}$ and $\beta_{i}$ are OLS parameters estimated through the regression of $R_{i t}$ on $R_{m t}$.

To measure the stock market reactions to the announcement of cross-border M\&As, the event window should be determined, which is the number of days over which there are possible abnormal returns caused by the event. A long window could dilute the possibility in finding any significant evidence. A short event window may not catch the effect of the event if the information comes out after the closing of the market and does not arrive in the public domain until the next day. Therefore, we use a 3-day, 5-day and 11-day event window to examine the stock market's short-term response to the merger and acquisition announcement (Aybar \& Ficici, 2009; Bhabra \& Huang, 2013). Furthermore, cumulative abnormal returns are calculated by summing the average AR for the days of the event window:

$C A R_{t}=\sum_{t=1}^{n} A R_{t}$

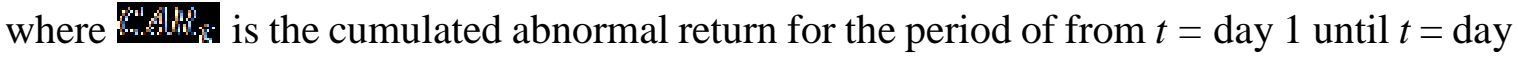

n.

To further assess whether the CAR is caused by the fluctuation of share prices, the statistical significance of the CARs is tested with $t$ statistic 


$$
t_{C A R}=\frac{C A R}{S_{C A R} / \sqrt{n}}
$$

where $S_{C A R}$ is the standard deviation of the cumulative abnormal returns. If the CAR observed during the announcement of Chinese cross-border M\&As is significantly different from zero, it can be concluded that this event has a significant impact on the acquiring firms' stock prices.

\section{Empirical results}

Table 3 presents the results of empirical analysis of the cumulative abnormal returns (CARs) of 165 cross-border M\&As by Chinese listed firms surrounding the cross-border merger and acquisition announcement dates. Around the announcement date, CARs are consistently positive with values of $0.84 \%, 0.89 \%$ and $1.22 \%$ for the $(-1,0),(0,+1)$ and $(-1,+1)$ windows, respectively. All of them are significant at the $1 \%$ and $5 \%$ level. The findings show that, on average, cross-border M\&As by Chinese listed firms generated a positive market reaction by producing positive abnormal returns to the shareholdings of acquiring firms, thus supporting Hypothesis 1a.

\section{Insert Table 3 near here}

Table 4 reports the empirical results of the cumulative abnormal returns based on acquiring firms listed in different stock markets. For those listed in the mainland market, the mean CARs range from $0.79 \%$ to $1.53 \%$ and are statistically significant for the period of $(-1,0),(0,1)$ and $(-1$, +1) during the announcement date. On the contrary, for those listed in the Hong Kong market, the mean CARs range from $-0.10 \%$ to $1.16 \%$. All of them are positive, but insignificant, except for the period of $(-2,+2)$. This finding shows that the positive market reaction is more significant in the mainland stock markets than that in the Hong Kong market. Thus, these results support Hypothesis 
$1 b$.

Insert Table 4 near here

As shown in Table 5a-5f, we investigate hypotheses $2 \mathrm{a}$ and $2 \mathrm{~b}$ by testing the six governance indicators one by one to compare the effect of different levels of each indicator on stock market performance. The findings show that for the shareholders of Chinese acquiring firms who have acquired the target firms from countries with a low level of political stability (e.g. VA and PS) and governance quality (e.g. GE, RQ, RL and CC), all of the CARs are insignificant. These indicate that the shareholders of Chinese acquiring firms who purchase target firms from such a country have not generated substantial positive announcement gains. Conversely, for the shareholders of Chinese acquiring firms who purchase target firms from a country with a high level of political stability and governance quality, the CARs for $(-1,0),(0,+1)$ and $(-1,+1)$ are all positive and statistically significant. These indicate that the announcement of cross-border M\&As for target firms from such a country have yielded highly significant wealth for the shareholders of acquiring firms surrounding the announcement date. The difference between the abnormal returns of acquiring firms that purchase target firms from countries with different levels of political stability and governance quality is illustrated in Tables 5a-5f. The results show that all the shareholders of acquiring firms that purchase target firms from a country with a high level of political stability and governance quality earn higher returns than those targeting firms from a country with a low level of political stability and governance quality. These further demonstrate that a high level of political stability and governance quality is perceived positively and this results in a high level of stock market performance. Taken together, the empirical evidence supports Hypothesis 2a and Hypothesis 2b.

Insert Table 5a-5f near here 
The results of testing the impact of the ownership status of Chinese acquiring firms are illustrated in Table 6. The results in the first two columns in Table 6 indicate that for SOE acquirers, the CARs for $(-1,0),(0,+1),(-1,+1)$ and $(-5,+5)$ are positive, but statistically insignificant. This suggests that the shareholders of Chinese SOE acquirers did not experience substantial positive wealth gains. Conversely, for privately owned firms (acquirers), the CARs show positive returns during all announcement dates. For the event window $(-1,0),(0,+1)$ and $(-1,+1)$, the shareholders of Chinese private firms experienced statistically significant positive CARs of $1.31 \%, 1.28 \%$ and $1.88 \%$, respectively. These results indicate that the announcement of the cross-border M\&As for private acquiring firms yielded highly significant wealth gain for their shareholders. The difference between the abnormal returns of the private acquirers and SOE acquirers is illustrated in Table 6 . The results indicate that cross-border M\&As created higher returns for the shareholders of Chinese private acquirers than those of Chinese SOE acquirers surrounding the announcement date, except for the period of $(-5,+5)$. Taken together, these findings are consistent with Hypothesis 3 .

Insert Table 6 near here

\section{Discussion}

\subsection{The main findings}

Accompanying the rapid development of the Chinese economy since the open door policy and economic reforms over past decades, Chinese firms are playing an increasingly important role in cross-border M\&A activities (Li, Li, \& Wang, 2016; Zheng, et al., 2016). However, we have limited understanding of the performance implications of such activities. This study examines the stock market reaction to cross-border M\&As by Chinese firms based on signalling theory and the institution-based view. The results indicate that cross-border M\&As by Chinese firms are 
interpreted by the stock market as strong signals released by Chinese acquirers which result in a significant, positive stock market reaction. This implies that M\&A activities by Chinese firms symbolize these firms' global ambitions and financial status, and are perceived as a spring board to acquiring strategic resources and capabilities abroad in order to seize opportunities and enhance competitive advantage in the global market. Thus, the announcement of cross-border M\&As is perceived positively and has resulted in an increase in stock prices through a positive stock market reaction.

Our findings are consistent with the majority of previous studies (Bhagat, Malhotra, \& Zhu, 2011; Boateng, Wang, \& Yang, 2008; Wang \& Boateng, 2007; Zhou, et al., 2015) on cross-border M\&As by EE firms, but are contrary to Aybar and Ficici’s study (2009) and Chen and Young's study (2010). Aybar and Ficici (2009) used a sample from 13 key emerging economies between 1991 and 2004, without including China. However, unlike other emerging economies (e.g. India, Russia, and Malaysia), Chinese firms’ cross-border M\&As have unique characteristics due to the unique institutional environment and may trigger different market reactions. This may be the main reason why our findings differ from those of Aybar and Ficici (2009). Chen and Young (2010) studied 39 deals by 32 Chinese firms from 2000 to 2008 and showed that the announcement of cross-border M\&As resulted in negative average CARs for Chinese acquirers. Their results are based on a relatively small sample which also includes foreign-invested companies within mainland China as acquired/target firms. Their sample period from 2000 to 2008 represented an early stage of cross-border M\&As by Chinese firms. These factors together may largely influence the empirical results and yield a different conclusion. Our findings drawn from a sample period up to 2012 may reflect the increasing importance of cross-border M\&As in the short-term market performance of Chinese listed firms due to the strong market reactions.

The findings show that there are asymmetric market reactions to cross-border M\&As by 
Chinese firms in mainland Chinese stock markets and the Hong Kong stock market. Different market reactions in these stock markets reflect the institutional arrangements of 'one country, two systems' cross China. The mainland Chinese stock markets behave differently from that in Hong Kong. The former exhibit good-news-chasing behaviour which generates more significant reactions to the same M\&A events than those in the Hong Kong stock market. This suggests that the 'one country, two markets' scenario results in different magnitudes of market perceptions. Investors in mainland China suffer from significant information asymmetries and limited investment options due to the underdeveloped capital market and thus they are more likely to overestimate the positive impact of cross-border M\&A deals compared with those in the Hong Kong stock market. This finding demonstrates that the impact of cross-border M\&As is affected by financial institutional arrangements.

Furthermore, we have evaluated the market performance implications of M\&As in terms of the target firms' countries of origin, with different levels of political risk, and the ownership status of the acquiring firms (SOEs vs private firms) from the institutional perspective. Chinese cross-border M\&As benefit from well-established institutions and a stable investment environment in target countries with a low level of political risk. These target countries may enable Chinese acquirers to access a high quality of strategic resources, technological knowledge and market knowledge which are not available in the domestic market or in other emerging economies. Thus, the shareholders of acquiring firms that purchase a target firm from an institutionally developed country with a low level of political risk can gain higher returns than those shareholders of acquiring firms who invest in countries with a high level of political risk. Chinese firms use cross-border M\&As to signal their quality, especially when targeting firms are from institutionally well-developed countries with a low level of political risk. This shows that cross-border M\&As enable Chinese firms to span national boundaries to gain strategic assets and credibly enhance their 
global reputation (Siegel, 2009), thus generating positive market reactions. Our findings are consistent with real-life events. For example, the announcement of ICBC's acquisition of Halim Bank Indonesia only resulted in a $0.54 \%$ increase in its share price in 2006. However, the announcement of ICBC's acquisition of BEA Canada resulted in a 4.15\% increase in share price in 2011.

The results suggest that cross-border M\&As have different performance implications for acquiring firms with different ownership status. More specifically, the shareholders of Chinese SOE acquirers experience lower CARs than those of Chinese private acquirers. The possible reason is that SOE acquirers face stronger institutional restrictions than private acquirers which may give a negative signal to investors, and this in turn is reflected in stock prices. The empirical results also reveal the hidden relationship between ownership status and the market performance of cross-border M\&As. The shareholders of Chinese SOE acquirers earn a lower level of abnormal returns than those of private acquirers. This finding implies that SOEs, as both economic and political actors, may carry the baggage embedded in the institutional environment of their home country, and investors may be sceptical about the political motivations of cross-border M\&As by SOE acquirers, thus resulting in lower shareholder value.

\subsection{Contributions}

Our study contributes to the existing literature in three main ways. First, unlike previous studies, we integrate signal theory and the institution-based view to examine the short-term performance implications of Chinese cross-border M\&As, and unpack what is behind such activities. The findings from our study provide new insights into cross-border M\&A value generation through market reactions and the extent to which short-term market performance reflects investors’ perception on the institutional characteristics of M\&A events. Although it is well documented that Chinese firms use cross-border M\&As as a strategic means of acquiring valuable 
technology, brands and managerial capability, there is a lack of evidence on the market reactions to this important strategic approach. Our study thus adds much needed evidence on the link between market reactions and the unique institutional characteristics embedded in cross-border M\&As by Chinese firms.

Second, this study takes a first step towards investigating the impact of the institutional setting of the financial markets on market reactions to cross-border M\&As by revealing the different magnitudes of such reactions under 'one country, two systems'. The findings imply that the short-term market performance of cross-border M\&As by Chinese firms is contingent on the development of the capital market. Investors in less developed capital markets may overestimate the positive impact of cross-border M\&As.

Third, this study explicitly evaluates the impact of various types of political risks on market reactions to cross-border M\&As by Chinese firms. Political stability and governance quality are two important components of political risks. By delineating political risk into different components, our research provides new insights into the link between different dimensions of political risks, and stock market reactions to M\&A announcements, and fills a research gap, given that there is a lack of research in this area. Additionally, we capture the impact of the ownership of the acquiring firms and contribute to a better understanding of the impact of ownership status on the short-term performance of cross-border M\&As from the institutional perspective. SOEs represent a product of the Chinese institutional environment, and their M\&A activities are perceived differently compared with privately owned firms, thus resulting in different short-term market performance. Therefore, our study further reveals the impact of the institutional dimension embedded in the ownership status of Chinese acquiring firms.

\subsection{Implications for management practice}

This study has a number of implications for practitioners and policy makers. First, our 
research shows that the announcement of cross-border M\&As by Chinese firms results in a positive stock market reaction which is more significant in the mainland China markets than in the Hong Kong market. This suggests that policy makers need to design appropriate regulations and further develop the capital market to avoid good-news-chasing behaviour by removing ownership restrictions, currency control and liquidity restrictions. Establishing a well-functional capital market can reduce the dramatic volatility of market reactions to cross-border M\&As by Chinese firms.

Second, our research draws attention to an important factor - political risk within target countries - which affects the market reaction to cross-border M\&As. China’s increased presence in Africa and other developing countries has raised concerns due to the high levels of political risk. The findings confirm the negative impact of political risk on market reactions to cross-border M\&As, and thus suggest that Chinese investors should be aware of the detrimental impact of political risk when acquiring target firms from those host countries. Therefore, Chinese managers who deal with cross-border M\&As should take political risk seriously to reduce their vulnerability and minimize loss when things go wrong. For policy makers of target countries, an improvement of the overall political environment is required when attracting future Chinese investment as firms may become cautious when making M\&A decisions in order to avoid a negative market reaction.

Third, the findings from our research provide useful guidance not only for Chinese acquiring firms that are expanding globally, but also for overseas target firms who are looking for buyers or investors in a bi-directional selection process. Our findings show that the shareholders of Chinese SOE acquirers experience lower cumulative abnormal returns than those of Chinese private acquirers when engaging in cross-border M\&As. Therefore, overseas target firms who are seeking buyers from emerging markets should keep in mind that state ownership may influence the financial market investors’ reactions. 


\subsection{Limitations and directions for future research}

There are some limitations in this research which point to avenues for future research. First, this study only focuses on cross-border M\&As undertaken by Chinese firms. Therefore, the findings may be specific to the research setting. Future research should extend the sample to other emerging economies, such as India, Brazil, Russia and South Africa. Second, due to data availability, only publicly listed firms have been investigated. Future research should consider non-listed Chinese firms in order to generate a more complete picture of the impact of cross-border M\&As by Chinese firms. Third, this study has mainly evaluated the impact of differences in China's stock markets, political risk and ownership structure on the short-term performance of

cross-border M\&As by Chinese firms. In particular, we have used fine-grained measures to capture different dimensions of political risk. However, other factors, including the characteristics of shareholders, a firm's industry, the state of management, unfavourable exchange rates, and the broad economic conditions of a host country and the home country can also affect market reactions. This represents a promising avenue for future studies. Fourth, we have only examined the short-term impact of cross-border M\&As on stock market performance. Future research should investigate the long-term performance implications of cross-border M\&As and reveal whether the same institutional factors and internal conditions have differing impacts on the short-term and long-term performance of cross-border M\&As by emerging market firms.

\section{Conclusion}

Adopting signalling theory and the institution-based view, this study examines how stock markets react to the announcement of cross-border M\&As by Chinese listed firms and whether institutional characteristics associated with cross-border M\&As generate different market reactions and result in different short-term market performance. An event study analysis based on a sample of Chinese 
listed firms from 2000 to 2012 finds that the stock market, on average, responded positively and significantly to cross-border M\&A announcements. The magnitude of such a market reaction to cross-border M\&A events is greater in the mainland Chinese stock markets than that of the Hong Kong stock market. This may indicate that the mainland China stock markets are underdeveloped and tend to overreact to cross-border M\&A announcements due to 'good-news-chasing' behaviour and irrational trading. We have further investigated the extent to which the political risk inherent in the target firms' country of origin and the ownership status of acquiring firms affect stock market reactions. The findings show that the level of political risk and SOE ownership are negatively associated with the short-term market performance of Chinese acquiring firms. Taken together, our study helps to provide new insights into the relationship between the short-term market performance and the institutional characteristics associated with cross-border M\&As by Chinese firms.

\section{References}

Ahlers, G. K. C., Cumming, D., Günther, C., \& Schweizer, D. D. (2015). Signaling in Equity Crowdfunding. Entrepreneurship Theory and Practice, 39(4), 955-980.

Arrow, K. (1968). Economic equilibrium, in R. Merton; D. Sills, International encyclopedia of the social sciences (vol. 4). London and New York: Macmiillan and the Free Press, 376-388.

Arrow, K. (1973). Higher education as a filter. Journal of Public Economics, 2(3), 193-216.

Arrow, K. (1959). Toward a theory of price adjustment, in Abramovitz Moses et al., The allocation of economic resources: essays in honor oof Bernard Francis Haley. Stanford, California: Stanford University Press.

Arrow, K. \& Debreu, G. (1954). Existence of an equilibrium for a competitive economy. Econometrica, 22(3), 265-290.

Asquith, P. (1983). Merger bids, uncertainty, and stockholder returns. Journal of Fianacial Economics, 11(1), 51-83.

Asquith, P., Brunel, R., \& Mullins, D. (1983). The gains of bidding firms from mergers. Jounal of 
Financal Ecomonics, 11(1), 121-139.

Athreye, S. \& Kapur, S. (2009). Introduction: The internationalization of Chinese and India firm-trends, motivations and strategy. Industrial \& Corporate Change, 18(2), 209-221.

Aybar, B. \& Ficici, A. (2009). Cross-border acquisitions and firm value: An analysis of emerging-market multinationals. Journal of International Business Studies, 40(8), 1317-1338.

Bai, C. E., Lu, J., \& Tao, Z. (2006). The multitask theory of state enterprise reform: Empirical evidence from China. Americal Economic Review, 96(2), 353-357.

Bekaert, G., Harvey, C. R., Lundblad, C. T., \& Siegel, S. (2014). Political risk spreads. Journal of International Business Studies, 45(4), 471-493.

Ben-Amar, W. \& Andre, P. (2006). Separation of ownership from control and acquiring firm performance: the case of family ownership in Canada. Journal of Business Finance and Accounting 33(3-4), 517-543.

Bergh, D. D., Connelly, B. L., Ketchen, D. J., \& Shannon, L. M. (2014). Signalling Theory and Equilibrium in Strategic Management Research: An Assessment and a Research Agenda. Journal of Management Studies, 51(8), 1334-1360.

Berry, H. (2006). Leaders, laggards and the pursuit of foreign knowledge. Strategic Management Journal, 27(2), 151-168.

Bhabra, H. S. \& Huang, J. (2013). An empirical investigation of mergers and acquisitions by Chinese listed companies, 1997-2007. Journal of Multinational Financial Management 23(3), 186-207.

Bhagat, S., Malhotra, S., \& Zhu, P. C. (2011). Emerging country cross-border acquisitions: Characteristics, acquirer returns and cross-sectional determinants. Emerging Markets Review, 12(3), 250-271.

Bilson, C. M., Brailsford, T. J., \& Hooper, V. J. (2002). The Explanatory Power of Political Risk in Emerging Markets. International Review of Financial Analysis, 11(1), 1-27.

Black, F. (1986). Noise. Journal of Finance, 41(3), 529-543.

Blanchard, O. \& Shleifer, A. (2001). Federalism with and without political centralization: China versus Russia. IMF staff papers, 48(special issue), 171-179.

Boateng, A., Wang, Q., \& Yang, T. L. (2008). Cross-border M\&As by Chinese firms: An analysis of strategic motives and performance. Thunderbird International Business Review, 50(4), 259-270.

Bradley, M., Desai, A., \& Kim, E. H. (1983). The rationale behind inter-firm tender offers: Information or synergy? Jounal of Financal Ecomonics, 11(1-4), 183-206.

Brouthers, K. D. \& Hennart, J. F. (2007). Boundaries of the firm: Insights from international entry mode research. Journal of Management, 33(3), 395-425. 
Brown, S. J. \& Warner, J. B. (1985). Using daily stock returns: the case of event studies. Journal of Fianacial Economics, 14(1), 3-31.

Bruner, R. F. (2002). Does M\&A Pay? A Survey of Evidence for the Decision-Maker. Journal of Applied Finance, 12(1), 7-27.

Bruton, G. D., Peng, M. W., Ahlstrom, D., Stan, C., \& Xu, K. (2015). State-owned enterprises around the world as hybrid organizations. Academy of Management Perspectives, 29(1), 92-114.

Buckley, P. J., Clegg, L. J., Cross, A. R., Liu, X., Voss, H., \& Zheng, P. (2007). The determinants of Chinese outward foreign direct investment Journal of International Business Studies, 38(4), 499-518.

Buckley, P. J., Elia, S., \& Kafouros, M. (2014). Acquisitions by emerging market multinationals: implications for firm performance. Journal of World Business, 49(4), 611-632.

Campa, J. M. \& Hernando, I. (2004). Shareholder value creation in European M\&As. European Financial Management, 10(1), 47-81.

Campa, J. M. \& Hernando, L. (2004). Shareholder wealth creation in European M\&As. European Financial Management, 10(1), 57-70.

Cantwell, J., Dunning, J. H., \& Lundan, S. M. (2010). An evolutionary approach to understanding international business activity: The co-evolution of MNEs and the institutional environment. Journal of International Business Studies, 41(3), 567-586.

Cao, C. \& Liu, G. (2013). Political uncertainty and cross-border mergers and acquisitions. available http://zicklin.baruch.cuny.edu/faculty/accountancy/events-research-workshops/Downloads/SWUF E-Chunfang_Cao.pdf.

Chakrabarti, A. \& Mitchell, W. (2013). The persistent effect of geographic distance in acquisition target selection. Organization Science, 24(6), 1805-1826.

Chan, Y. \& Wei, K. C. (1996). Political risk and stock price volatility: The case of Hong Kong. Pacific-Basin Finance Journal, 4(2-3), 259-275.

Chari, A., Ouimet, P., \& Tesar, L. (2010). The value of control in emerging markets. Review of Financial Studies, 23(4), 1741-1770.

Chen, C. \& Shih, H. T. (2008). Mergers and Acquisitions in China: Impacts of WTO Accession. Edward Elgar: MA.

Chen, S. (2008). The motives for international acquisitions: Capability procurements, strategic considerations, and the role of ownership structures. Journal of International Business Studies, 39(3), 454-471.

Chen, S. J. (2008). China's Go Out' Policy A One-Way Street. Forbes magazine. 
Chen, Y. Y. \& Young, M. N. (2010). Cross-border Mergers and Acquisitions by Chinese Listed Companies: A principal-principal Perspective. Asia Pacific Journal of Management, 27(23), 523-539.

Child, J. \& Rodrigues, S. B. (2005). The internationalization of Chinese firms: A case for theoretical Extension. Management and Organization Review, 1(3), 381-410.

China.org.cn. (2008). One Cuntry, Two Systems.

Chung, C. C. \& Beamish, P. W. (2005). The impact of institutional reforms on characteristics and survival of foreign subsidiaries in emerging economies. Journal of Management Studies 42(1), 35-62.

Clifford, P. (2012). The FACE RAS: Strategic benefits and applications. Nottingham: FACE Recording \& Measuring Systems.

Conn, R. L., Cosh, A., Guest, P., \& Hughes, H. (2005). The impact on UK acquirers of domestic, cross-border, public and private acquisitions. Journal of Business Finance and Accounting, 32(5-6), 815-870.

Cuervo-Cazurra, A. (2008). The multinationalization of developing country MNEs: the case of Multinatinas. Journal of International Management, 13(3), 258-277.

Cuervo-Cazurra, A. (2006). Who cares about corruption? Journal of International Business Studies, 37(6), 803-822.

Cui, L. \& Jiang, F. (2012). State ownership effect on firms' FDI ownership decisions under institutional pressure: a study of Chinese outward-investing firms. Journal of International Business Studies, 43(3), 264-284.

Cui, L., Meryer, K. E., \& Hu, H. W. (2014). What drives firms' intent to seek strategic assets by foreign direct investment? A study of emerging economy firms. Journal of World Business, 49(4), 488-501.

Delios, A. \& Henisz, W. J. (2003). Political Hazards and the Sequence of Entry by Japanese Firms. Journal of International Business Studies, 34(3), 227-241.

Deng, P. (2007). Investing for strategic resources and its rationale: The case of outward FDI from Chinese companies. Business Horizons, 50(1), 71-81.

Deng, P. (2010). What determines firm value of cross-border M\&As by Chinese firms? An absorptive capacity perspective. Thunderbird International Business Review, 52(6), 509-524.

Deng, P. \& Yang, M. (2015). Cross-border Mergers and Acquisitions by Emerging Market Firms: A Comparative Investigation. International Business Review, 24(1), 157-172.

Dodd, P. (1980). Merger proposals, management discretion and stockholder wealth. Journal of Financial Economics, 8(2), 105-138. 
Doukas, J. \& Travlos, N. G. (1998). The effect of corporate multinationalism on Shareholders' wealth: Evidence from International Acquisitions. The Journal of Finance, 43(5), 1161-1175.

Dunning, J. H. \& Lundan, S. M. (2008). Institutions and the OLI paradigm of the multinational enterprise. Asia Pacific Journal of Management, 25(4), 573-593.

Dutta, S., Saadi, S., \& Zhu, P. (2013). Does payment method matter in cross-border acquisitions? . International Review of Economics and Finance, 25(1), 91-107.

Eckbo, B. E. \& Thorburn, K. S. (2009). Gains to bidder firms revisited: domestic and foreign acquisitions in Canada. Financial Quantitative Analysis, 35(1), 1-25.

Economist. (2010). China buys up the world. http://www.economist.com/node/17463473.

Faccio, M., McConnell, J. J., \& Stolin, D. (2006). Returns to acquirers of listed and unlisted targets. Journal of Financial and Quantitative Analysis, 41(1), 197-220.

Fama, E. F. (1991). Efficient capital markets: II. Journal of Finance, 46(5), 1575-1617.

Feinberg, S. \& Gupta, A. (2009). MNC subsidiaries and country risk: Internalization as a safeguard against weak external institutions. Academy of Management Journal, 52(2), 381-399.

Firth, M. (1980). Takeovers, shareholder returns and the theory of the firm. The Quarterly Journal of Economics, 94(2), 235-260.

Floreani, A. \& Rigamonti, S. (2001). Mergers and shareholders wealth in the insurance industry. University Cattolica del Sacro Cuore.

Gao, L., Liu, X., \& Lioliou, E. (2015). A double-edged sword: The impact of institutions and political relations on the international market expansion of Chinese state-owned enterprises. Journal of Chinese Economic and Business Studies, 13(2), 105-125.

Gaur, A. S., Delios, A., \& Singh, K. (2007). Institutional environments, staffing strategies, and subsidiary performance. Journal of Management, 33(4), 611-636.

Gaur, A. S., Malhotra, S., \& Zhu, P. (2013). Acquisition announcements and stock market valuations of acquiring firms' rivals: A test of the growth probability hypothesis in China. Strategic Management Journal, 34(2), 215-232.

Ghosh, A. (2001). Does operating performance really improve following corporate acquisitions? Journal of Corporate Finance, 7(2), 151-178.

Globerman, S. \& Shapiro, D. (2009). Economic and strategic considerations surrounding Chinese FDI in the United States. Asia Pacific Journal of Management, 26(1), 163-183.

Goergen, M. \& Renneboog, L. (2004). Shareholder wealth effects of european domestic and cross border takeover bids. European Financial Management, 10(1), 9-45.

Gregory, A. \& McCorriston, S. (2005). Foreign acquisitions by UK limited companies: short-run 
and long-run performance. Journal of Empirical Finance, 12(1), 99-125.

Grossman, S. J. \& Hart, O. D. (1981). The allocational role of takeover bids in situations of asymmetric information. Journal of Finance, 36(2), 253-270.

Gubbi, S., Aulakh, P., Pay, S., Sarkar, M., \& Chittoor, R. (2010). Do international acquisitions by emerging-economy firms create shareholder value: The case of India firms. Journal of International Business Studies, 41(3), 391-418.

Guler, I. \& Guillen, M. F. (2010). Institutions and the Internationalisation of US Venture Capital Firms. Journal of International Business Studies, 41(2), 185-205.

Haleblian, J. \& Finkelstein, S. (1999). The influence of organizational acquisition experience on acquisition performance: a behavioral learning perspective. Administrative Science Quarterly, 44(1), 29-56.

Harzing, A.-W. \& Pudelko, M. (2016). Do we need to distance ourselves from the distance concept? Why home and host country context might matter more than (cultural) distance. Management International Review, 56(1), 1-34.

Holl, P. \& Kyriazis, D. (1997). Wealth creation and bid resistance in UK takeover bids. Strategic Management Journal, 18(6), 483-498.

Holmes, R. M., Miller, T., Hitt, M. A., \& Salmador, M. P. (2013). The interrelationships among informal institutions, formal institutions, and inward foreign direct investment. Journal of Management, 39(2), 531-566.

Hutchison, M. L. \& Gibler, D. M. (2007). Political tolerance and territorial threat: A cross-national study. Journal of Politics, 69(1), 128-142.

Kang, J. K., Shivdasani, A., \& Yamada, T. (2000). The effect of bank relations on investment decisions: an investigation of Japanese takeover bids. Journal of Finance, 55(5), 2197-2218.

Kaufmann, D., Kraay, A., \& Mastruzzi, M. (2010). The worldwide governance indicators: methodology and analytical issues. Policy Research Working Paper Series 5430, The World Bank.

Kim, H. \& Mei, J. (2001). What makes the stock market jump? An analysis of political risk on Hong Kong market returns. Journal of International Money and Finance, 20(7), 1003-1016.

Kirmani, A. \& Rao, A. R. (2000). No pain, no gain: A critical review of the literature on signaling unobservable product quality. Journal of marketing, 64(2), 66-79.

Kostova, T., Roth, K., \& Dacin, M. T. (2008). Institutional theory in the study of multinational corporations: A critique and new directions. Academy of Management Review, 33(4), 994-1006.

Kruse, T. A., Park, H. Y., Park, K., \& Suzuki, K. (2007). Long-term performance following mergers of Japanese companies: the effect of diversification and affiliation. Pacific-Basin Finance Journal, 15(2), 154-172. 
Lang, L., Stulz, R. M., \& Walking, R. A. (1989). Managerial performance, Tobin's q and gains from successful tender offers. Journal of Financial Economics, 24(1), 137-154.

Lang, L. H. P., Stulz, R. M., \& Walking, R. A. (1991). A testing of the free cash flow hypothesis: the case of bidder returns. Journal of Fianacial Economics, 29(2), 315-335.

Langetieg, T. (1978). An application of a three-factor performance index to measure stockholders gains from mergers. Journal of Financial Economics, 6(4), 365-384.

Lebedev, S., Peng, M. W., Xie, E., \& Stevens, C. E. (2015). Mergers and acquisitions in and out of emerging economies. Journal of World Business, 50(4), 651-662.

Li, J., Li, P., \& Wang, B. (2016). Do cross-border acquisitions create value? Evidence from overseas acquisitions by Chinese firms. International Business Review, 25(2), 471-483.

Lin, X. (2010). State versus versus private MNCs from China: Initial conceptualizations. International Marketing Review, 27(3), 366-380.

Liu, X., Gao, L., Lu, J., \& Lioliou, E. (2016). Environmental risks, localization and the overseas subsidiary performance of MNEs from an emerging economy. Journal of World Business, 51(3), 356-368.

Lourenço, I. C., Callen, J. L., Branco, M. C., \& Curto, J. D. (2014). The value relevance of reputation for substainability leasdership. Journal of Business Ethics, 119(1), 17-28.

Lu, J., Liu, X., Wright, M., \& Filatotchev, I. (2014). FDI Location Choices of Chinese Firms: The moderating Effects of Home Country Government Support and Host Country Institutions on Internationalization Experience. Journal of International Business Studies, 45(4), 428-449.

Luo, Y., Xue, Z., \& Han, B. (2010). How emerging market governments promote outward FDI: experience from China. Journal of World Business, 45(1), 68-79.

Martynova, M. \& Renneboog, L. (2008). A century of corporate takeovers: what have we learned and where do we stand? Journal of Banking and Finance, 32(10), 2148-2177.

Masulis, R. W., Wang, C., \& Xie, F. (2007). Corporate governance and acquirer returns. Journal of Finance, 62(4), 1851-1889.

McWilliams, A. \& Siegel, D. (1997). Event studies in management research: theoretical and empirical issues. The Acdemy of Management Journal, 40(3), 626-657.

Mitchell, M. L. \& Stafford, E. (2000). Managerial decesions and long-term stock price performance. Journal of Business, 73(3), 287-329.

Moeller, S. B. \& Schlingemann, F. P. (2005). Global diversification and bidder gains: A comparison between cross-border and domestic acquisitions. Journal of Banking and Finance, 25(3), 533-564.

Morck, R., Shleifer, A., \& Vishny, R. W. (1990). Do managerial objectives drive bad acquisitions? 
The Journal of Finance, 45(1), 31-48.

Moss, T. W., Neubaum, D. O., \& Meyskens, M. (2015). The effect of virtuous and entrepreneurial orientations on microfinance lending and repayment: A signaling theory perspective. Entrepreneurship Theory and Practice, 39(1), 27-52.

Nelson, P. (1970). Information and consumer behavior. Journal of Political Economy, 78(2), 311-329.

New.cn. (2011). Libya unrest, How much did Chinese business lose?, Xinhua Net. http://news.xinhuanet.com/fortune/2011-03/25/c_121230630.htm.

Nicholson, R. \& Salaber, J. (2013). The motives and performance of cross-border acquirers from emerging economies: Comparison between Chinese and Indian firms. International Business Review, 22(6), 963-980.

Ning, L., Kuo, J., Strange, R., \& Wang, B. (2014). International investors' reactions to cross-border acquisitions by emerging market multinationals. International Business Review, 23(4), 811-923.

North, D. C. (1990). Institutions, Institutional change, and economic performance. Cambridge, MA: Harvard University Press.

OECD. (2008). Comparative report on corporate governance of state-owned enterprises.

Ozmel, U., Reuer, J. J., \& Gulati, R. (2013). Signals across Multiple Networks: How Venture Capital and Alliance Networks Affect Interorganizational Collaboration. Academy of Management Journal, 56(3), 852-866.

Pangarkar, N. \& Lim, H. (2003). Performance of foreign direct investment from Singapore. International Business Review, 12(5), 601-624.

P“stor, ŏ. \& Veronesi, P. (2013). Political uncertainty and risk premia. Journal of Financial Economics, 110(3), 520-545.

P“stor, ŏ . \& Veronesi, P. (2012). Uncertainty about government policy and stock prices. Journal of Finance, 67(4), 1219-1264.

Pazarskis, M., Vogiatzogloy, M., Christodoulou, P., \& Drogalas, G. (2006). Exploring the improvement of corporate performance after mergers - the case of Greece. International Research Journal of Finance and Economics, 1(6), 184-192.

Peng, M. W. (2000). Business strategies in transition economies. Thousand Oaks, CA: Sage.

Peng, M. W. (2001). How entrepreneurs create wealth in transition economies. The Acdemy of Management Executive, 15(1), 95-108.

Peng, M. W., Wang, D., \& Jiang, Y. (2008). An institution-base view of international business strategy: a focus on emerging economies. Journal of International Business Studies, 39(5), 920-936. 
Peng, M. W., Wang, D., \& Tong, T. W. (2004). Ownership types and strategic groups in an emerging economy. Journal of Management Studies, 41(7), 1105-1129.

Pettway, R. H. \& Yamada, T. (1986). Mergers in Japan and their impacts upon stockholders' wealth. Financial Management, 15(4), 43-52.

Priem, R. L., Li, S., \& Carr, J. C. (2012). Insights and new directions from demand-side approaches to technology innovation, entrepreneurship, and strategic management research. Journal of Management, 38(1), 346-374.

Ragozzino, R. (2009). The effects of geographic distance on the foreign acquisition activity of U.S. firms. Management International Review, 49(4), 509-535.

Renwick, D., Redman, T., \& Maguire, S. (2012). Green human resource management: a review and research agenda. International Journal of Management Review, 15(1), 1-14.

Reuer, J. J. \& Ragozzino, R. (2012). The choice between joint ventures and acquisitions: insights from signaling theory. Organization Science, 23(4), 1175-1190.

Ross, S. A. (1977). The determination of financial structure: The incentive signaling structure. Bell Journal of Econimics, 8(1), 23-40.

Rui, H. C. \& Yip, G. S. (2008). Foreign acquisitions by Chinese firms: A strategic intent perspective. Journal of World Business, 43(2), 213-226.

Schwens, C., Eiche, J., \& Kabst, R. (2011). The moderating impact of informal institutional distance and formal institutional risk on SME entry mode choice. Journal of Management Studies, 2(48), 330-351.

Schwert, G. W. (2000). Hostility in takeovers: in the eyes of the beholder? Journal of Finance, 55(6), 2599-2640.

Scott, W. R. (1995). Institutions and organizations. London: Sage.

Sharma, D. S. \& Ho, J. (2002). The impact of acquisitions in operating performance: some Australian evidence. Journal Business Finance Account, 29(1-2), 155-200.

SHSE. (2014). Shanghai Stock Exchange Statistical Yearbook.

Siegel, D. S. (2009). Green management matters only if it yields more green: An economic/strategic perspective. Academy of Management Perspectives, 23(3), 5-16.

Smith, A. \& Kim, J. (1994). The combined effects of free cash flow and financial slack on bidder and target stock returns. Journal of Business, 67(2), 281-310.

Song, M. H. \& Walking, R. A. (2004). Anticipation acquisitions and bidder return puzzle. Working Paper, Ohio State University.

Spence, A. M. (1973). Job market signaling. Quarterly Journal of Economics, 87(3), 355-374. 
Spence, A. M. (1974). Market signaling: Informational transfer in hiring and related screening processes. Cambridge, MA: Harvard University Press.

Spence, A. M. (2002). Signaling in retrospect and the informational structure of markets. Americal Economic Review, 92(3), 434-459.

Sudarsanam, S., Holl, P., \& Salami, A. (1996). Shareholder Wealth Gains in Mergers: Effect of Synergy and Ownership Structure. Journal of Business Finance and Accounting, 23(5-6), 673-698.

Sudarsanam, S. \& Mahate, A. A. (2003). Glamour acquirers, method of payment and post-acquisition performance: the UK evidence. Journal of Business Finance and Accounting, 30(1-2), 299-341.

Sun, Q. \& Tong, W. H. S. (2003). China share issue privatization: The extent of success. Journal of Fianacial Economics, 70(2), 183-222.

Sun, Q., Tong, W. H. S., \& Tong, J. (2002). How does government ownership affect firm value? Evidence from China's privatization experience. Journal of Business Finance and Accounting, 29(1), 1-27.

Sun, S. L., Peng, M. W., Ren, B., \& Yan, D. (2012). A comparative ownership advantage framework for cross-border M\&As: The rise of Chinese and Indian MNEs. Journal of World Business, 47(1), 4-16.

Tian, L. H. \& Estrin, S. (2008). Retained state shareholding in Chinese PLC: Does government ownership always reduce corporate value? Journal of Comparative Economics, 36(1), 74-89.

Uhlenbruck, K., Rodriguez, P., Doh, J., \& Eden, L. (2006). The impact of corruption on entry strategy: Evidence from telecommunication projects in emerging economies. Organization Science, 17(3), 402-414.

Walker, M. (2000). Corporate takeovers, strategic objectives, and acquiring-firm shareholder wealth. Financial Management, 29(1), 53-66.

Wan, W. \& Hoskisson, R. (2003). Home country environments, corporate diversification strategies, and firm performance. Academy of Management Journal, 46(1), 27-45.

Wang, C., Hong, J., Kafouros, M., \& Wright, M. (2012). Exploring the role of government involvement in outward FDI from emerging economies. Journal of International Business Studies, 43(7), 655-676.

Wang, P., Liu, A., \& Wang, P. J. (2004). Return and risk interactions in Chinese stock markets. Journal of International Financial Markers, Institutions \& Money, 14(4), 367-384.

Wang, Q. \& Boateng, A. (2007). Cross-border M\&As by Chinese firms: An analysis of strategic motivation and performance. International Management Review, 3(4), 19-29.

Wang, S. \& Jiang, L. (2004). Location of trade, ownership restrictions, and market illiquidity: 
Examining Chinese A- and H-shares. Journal of Banking and Finance, 28(6), 1273-1297.

Williamson, O. E. (1985). The economic institutions of capitalism: firms, markets, relational contracting. New York: The Free Press.

Witt, M. A. \& Lewin, A. Y. (2007). Outward foreign direct investment as escape response to home country institutional constraints. Journal of International Business Studies, 38(4), 579-594.

Wu, C. \& Xie, N. (2010). Determinants of cross-border merger \& acquisition performance of Chinese enterprises. Procedia - Social and Behavioral Sciences, 2(5), 6896-6905.

Yeh, Y. \& Lee, T. (2000). The interaction and volatility asymmetry of unexpected returns in the greater China stock markets. Global Finance Journal, 11(1-2), 129-149.

Yeung, W. H. \& Huang, X. (2014). 'One Country Two Systems' as bedrock of Hong Kong's continued success: fiction or reality? Boston College Internationsl \& Comarative Law Review, $38(2), 14-25$.

Zhang, J., Zhou, C., \& Ebbers, H. A. (2011). Completion of Chinese overseas acquisitions: Institutional perspectives and evidence. International Business Review, 20(2), 226-238.

Zheng, N., Wei, Y., Zhang, Y., \& Yang, J. (2016). In search of strategic assets through cross-border merger and acquisitions: Evidence from Chinese multinational enterprises in developed economies. International Business Review, 25(1), 177-186.

Zhou, B., Guo, J., Hua, J., \& Doukas, A. (2015). Does state ownership drive M\&A performance? Evidence from China. European Financial Management, 21(1), 79-105.

Zhou, C. \& Witteloostuijn, A. (2010). Institutional constraints and ecological processes: Evolution of foreign-invested enterprises in the Chinese construction industry,1993-2005. Journal of International Business Studies, 41(3), 539-556.

Zhu, P. C. \& Malhotra, S. (2008). Announcement effect and price pressure: an empirical study of cross-border acquisitions by India firms. International Research Journal of Finance and Economics, 13(2), 24-41. 
Table 1: A summary of existing studies on the link between cross-border M\&As and stock market performance

\begin{tabular}{|c|c|c|c|c|}
\hline Market & Author(s), (year) & Sample period & Details of Sample & Findings \\
\hline \multicolumn{5}{|c|}{ Panel A: Developed markets } \\
\hline US & Dodd (1980) & $1970-1977$ & 151 takeovers & $\begin{array}{l}-0.23 \% \text { cumulative abnormal return on the } \\
\text { announcement date from completed bids }\end{array}$ \\
\hline US & $\begin{array}{l}\text { Bradley et al. } \\
\text { (1983) }\end{array}$ & $1962-1980$ & $\begin{array}{l}241 \text { successful deals, } \\
94 \text { unsuccessful deals }\end{array}$ & $\begin{array}{l}-0.64 \% \text { insignificant returns for the } \\
\text { unsuccessful bidders over }-20 \text { and }+20 \text { days } \\
\text { period }\end{array}$ \\
\hline US & $\begin{array}{l}\text { Lang et al. } \\
\text { (1989) }\end{array}$ & 1968-1986 & $\begin{array}{l}87 \text { targets and bidders } \\
\text { from successful } \\
\text { tender offers }\end{array}$ & $\begin{array}{l}\text { Negative impact on bidder returns when the } \\
\text { bid is made by a firm with a low Tobin's } q\end{array}$ \\
\hline US & $\begin{array}{l}\text { Smith and Kim } \\
\text { (1994) }\end{array}$ & 1980-1986 & $\begin{array}{l}177 \text { bidders and } \\
\text { targets }\end{array}$ & $\begin{array}{l}0.23 \% \text { significant abnormal returns over }-1 \\
\text { and } 0 \text { days }\end{array}$ \\
\hline US & $\begin{array}{l}\text { Floreani and } \\
\text { Rigamonti } \\
\text { (2001) }\end{array}$ & 1996-2000 & 56 listed acquirers & $\begin{array}{l}\text { 3.65\%.abnormal returns obtained by } \\
\text { insurance companies }\end{array}$ \\
\hline US & $\begin{array}{l}\text { Song and } \\
\text { Walking (2004) }\end{array}$ & $1985-2001$ & $\begin{array}{l}5726 \text { mergers and } \\
\text { acquisitions }\end{array}$ & $\begin{array}{l}\text { Acquiring firms with a period of more than } \\
\text { one year of 'dormant' bid activity receive a } \\
\text { positive abnormal return of } 0.8 \% \text {. Acquirers } \\
\text { with a 'dormant' period of less than one year } \\
\text { earn insignificant returns }\end{array}$ \\
\hline US & $\begin{array}{l}\text { Faccio et al. } \\
\text { (2006) }\end{array}$ & 1996-2001 & $\begin{array}{l}4429 \text { acquirers of } \\
\text { listed and unlisted } \\
\text { targets }\end{array}$ & $\begin{array}{l}-0.38 \% \text { significant abnormal returns for } \\
\text { acquirers of unlisted targets, while } 1.48 \% \\
\text { significant abnormal returns for acquirers }\end{array}$ \\
\hline US & $\begin{array}{l}\text { Masulis et al. } \\
\text { (2007) }\end{array}$ & $1990-2003$ & $\begin{array}{l}3333 \text { completed } \\
\text { acquisitions }\end{array}$ & $\begin{array}{l}\text { Acquires operating in more competitive } \\
\text { industries or separating the positions of CEO } \\
\text { and chairman of the board experience higher } \\
\text { abnormal announcement returns }\end{array}$ \\
\hline UK & $\begin{array}{l}\text { Holl and } \\
\text { Kyriazis (1997) }\end{array}$ & 1979-1989 & 178 successful bids & $\begin{array}{l}-1.25 \% \text { significantly negative abnormal } \\
\text { returns for bidders over the two months after } \\
\text { the bid announcement }\end{array}$ \\
\hline UK & $\begin{array}{l}\text { Sudarsanam and } \\
\text { Mahate (2003) }\end{array}$ & 1983-1995 & 519 listed acquirers & $\begin{array}{l}\text { between }-1.39 \% \text { and }-1.47 \% \text { significantly } \\
\text { negative abnormal returns for UK acquirers }\end{array}$ \\
\hline UK & $\begin{array}{l}\text { Conn et al., } \\
\text { (2005) }\end{array}$ & 1984-1998 & 4344 acquisitions & $\begin{array}{l}\text { Significantly positive announcement returns } \\
\text { for bidders when the culture difference is } \\
\text { great between U.K. bidders firms and foreign } \\
\text { target firms }\end{array}$ \\
\hline UK & $\begin{array}{l}\text { Gregory and } \\
\text { McCorriston } \\
(2005)\end{array}$ & 1985-1994 & 343 acquisitions & $\begin{array}{l}\text { Short-run returns are insignificantly different } \\
\text { from zero irrespective of the location of the } \\
\text { acquisition }\end{array}$ \\
\hline EU & $\begin{array}{l}\text { Campa and } \\
\text { Hernando (2004) }\end{array}$ & $1998-2000$ & $\begin{array}{l}262 \text { mergers and } \\
\text { acquisitions }\end{array}$ & $\begin{array}{l}-1.96 \% \text { negative abnormal returns for } \\
\text { regulated EU acquirers over } 60 \text { days around } \\
\text { the bid announcement. No significant returns } \\
\text { for bidders from unregulated industries for } \\
\text { the same period }\end{array}$ \\
\hline EU & $\begin{array}{l}\text { Goergen and } \\
\text { Renneboog } \\
(2004)\end{array}$ & $1993-2000$ & 187 bidders & $\begin{array}{l}1.2 \% \text { significantly cumulative abnormal } \\
\text { returns for bidders over } 5 \text { days around the } \\
\text { announcement date }\end{array}$ \\
\hline EU & $\begin{array}{l}\text { Chari et al. } \\
\text { (2010) }\end{array}$ & 1986-2006 & $\begin{array}{l}594 \text { acquisitions in } \\
\text { emerging markets and } \\
1624 \text { acquisitions in } \\
\text { developed markets }\end{array}$ & $\begin{array}{l}1.16 \% \text { significantly positive abnormal } \\
\text { returns for developed-marker acquirers over } \\
\text { a three-day event window }\end{array}$ \\
\hline Canada & $\begin{array}{l}\text { Ben-Amar and } \\
\text { Andre (2006) }\end{array}$ & $1998-2000$ & $\begin{array}{l}238 \text { mergers and } \\
\text { acquisitions by } 138 \\
\text { Canadian firms }\end{array}$ & $\begin{array}{l}1.6 \% \text { abnormal returns for acquiring firms } \\
\text { over } 3 \text { days }\end{array}$ \\
\hline Canada & $\begin{array}{l}\text { Dutta et al. } \\
\text { (2013) }\end{array}$ & 1993-2002 & $\begin{array}{l}1300 \text { completed } \\
\text { acquisitions }\end{array}$ & $\begin{array}{l}\text { Significantly positive abnormal returns for } \\
\text { Canadian acquiring firms' shares around the } \\
\text { announcement date }\end{array}$ \\
\hline \multicolumn{5}{|c|}{ Panel B: Emerging market } \\
\hline India & $\begin{array}{l}\text { Gubbi et al. } \\
\text { (2010) }\end{array}$ & $2000-2007$ & $\begin{array}{l}425 \text { cross-border } \\
\text { acquisitions by Indian } \\
\text { firms }\end{array}$ & $\begin{array}{l}\text { International acquisitions by Indian firms } \\
\text { earn significantly positive value for their } \\
\text { shareholders }\end{array}$ \\
\hline
\end{tabular}




\begin{tabular}{|c|c|c|c|c|}
\hline $\begin{array}{l}\text { India and } \\
\text { China }\end{array}$ & $\begin{array}{l}\text { Nicholson and } \\
\text { Salaber (2013) }\end{array}$ & $2000-2010$ & $\begin{array}{l}203 \text { Indian and } 63 \\
\text { Chinese cross-border } \\
\text { deals }\end{array}$ & $\begin{array}{l}\text { Cross-border acquisitions made by Indian } \\
\text { and Chinese firms lead to significant } \\
\text { shareholder wealth creation. Indian } \\
\text { shareholders are more likely to benefit from } \\
\text { deals in small culture distance countries, } \\
\text { While Chinese investors gain from } \\
\text { cross-border expansion of manufacturing } \\
\text { companies }\end{array}$ \\
\hline China & $\begin{array}{l}\text { Chen and Young } \\
\text { (2010) }\end{array}$ & 2000-2008 & $\begin{array}{l}39 \text { deals by } 32 \\
\text { Chinese MNEs }\end{array}$ & $\begin{array}{l}\text { Negative average cumulated abnormal } \\
\text { returns for Chinese acquiring MNEs }\end{array}$ \\
\hline China & $\begin{array}{l}\text { Ning et al. } \\
\text { (2014) }\end{array}$ & $1991-2010$ & 335 acquisitions & $\begin{array}{l}\text { Significant positive shareholder value for } \\
\text { Chinese acquiring MNEs }\end{array}$ \\
\hline $\begin{array}{l}\text { Emerging } \\
\text { market }\end{array}$ & $\begin{array}{l}\text { Aybar and Ficici } \\
\text { (2009) }\end{array}$ & $1991-2004$ & $\begin{array}{l}433 \text { acquisitions by } 58 \\
\text { emerging-market } \\
\text { multinationals }\end{array}$ & $\begin{array}{l}\text { The equity markets react negatively to the } \\
\text { emerging market cross-border acquisition } \\
\text { announcement }\end{array}$ \\
\hline $\begin{array}{l}\text { Emerging } \\
\text { market }\end{array}$ & $\begin{array}{l}\text { Bhagat et al. } \\
\text { (2011) }\end{array}$ & 1991-2008 & $\begin{array}{l}698 \text { acquisitions by } \\
\text { publicly listed firms } \\
\text { from eight emerging } \\
\text { countries }\end{array}$ & $\begin{array}{l}\text { Emerging country acquirers experience a } \\
\text { positive and significant market response of } \\
1.09 \% \text { on the announcement day }\end{array}$ \\
\hline
\end{tabular}

Table 2: Information on the sample firms

\begin{tabular}{lccccc}
\hline & $\mathrm{N}$ & $\begin{array}{c}\% \text { of } \\
\text { sample }\end{array}$ & & $\mathrm{N}$ & $\begin{array}{c}\% \text { of } \\
\text { sample }\end{array}$ \\
\hline Acquirers' industry & & & Target Country & & \\
SIC 10-14 Mining & 19 & $12.00 \%$ & $\begin{array}{l}\text { Europe } \\
\text { Asia/Pacific }\end{array}$ & 34 & $20.61 \%$ \\
SIC 20-39 Manufacturing & 97 & $58.79 \%$ & & & $49.09 \%$ \\
SIC 40-49 Transportation and & & & & & \\
communications & 7 & $4.24 \%$ & North America & 38 & $23.03 \%$ \\
$\quad$ SCI 50-59 Wholesale and Retail & 8 & $4.85 \%$ & Others & 12 & $7.27 \%$ \\
SIC 60-67 Finance & 20 & $12.12 \%$ & Total & 165 & \\
SIC 70-89 Services & 14 & $8.48 \%$ & & & \\
Total & 165 & & & & \\
& & & & & \\
Ownership status of acquirers & & & & & \\
$\quad$ State-owned & 69 & $41.82 \%$ & & & \\
Private & 96 & $58.18 \%$ & & & \\
$\quad$ Total & 165 & & & & \\
\hline
\end{tabular}


Table 3: Cumulative abnormal returns (CARs) for Chinese acquiring firms

\begin{tabular}{lcccccc}
\hline & $\mathrm{N}$ & Mean & s.d. & t-Stat & Positive: negative & $\%$ positive \\
\hline CAR $(-1,0)$ & 165 & 0.0084 & 0.0402 & $2.682^{* * *}$ & $92: 73$ & $55.76 \%$ \\
CAR $(0,+1)$ & 165 & 0.0089 & 0.0503 & $2.275^{* *}$ & $86: 79$ & $52.12 \%$ \\
CAR $(-1,+1)$ & 165 & 0.0122 & 0.0539 & $2.902^{* * *}$ & $93: 72$ & $56.36 \%$ \\
CAR $(-2,+2)$ & 165 & 0.0050 & 0.0718 & 0.890 & $89: 76$ & $53.94 \%$ \\
CAR $(-5,+5)$ & 165 & 0.0093 & 0.0936 & 1.278 & $80: 85$ & $51.52 \%$ \\
\hline${ }^{*}<<0.1,{ }^{* *} \mathrm{p}<0.05,{ }^{* * *} \mathrm{p}<0.01$ & & & &
\end{tabular}

Table 4: Market reactions: Mainland China vs. Hong Kong

\begin{tabular}{|c|c|c|c|c|c|c|c|c|}
\hline \multirow{2}{*}{ Event window } & \multicolumn{3}{|c|}{ Mainland } & \multicolumn{3}{|c|}{ Hong Kong } & \multicolumn{2}{|c|}{ Market effect } \\
\hline & $\mathrm{N}$ & Mean $\mathrm{CAR}_{\mathrm{M}}$ & t-Stat & $\mathrm{N}$ & Mean $\mathrm{CAR}_{\mathrm{H}}$ & t-Stat & $\mathrm{CAR}_{\mathrm{M}^{-}}-\mathrm{CAR}_{\mathrm{H}}$ & $\mathrm{t}$-Value \\
\hline $\operatorname{CAR}(-1,0)$ & 103 & 0.0133 & $2.997^{* * *}$ & 62 & 0.0003 & 0.079 & 0.0130 & 1.037 \\
\hline $\operatorname{CAR}(0,+1)$ & 103 & 0.0104 & $2.372^{* *}$ & 62 & 0.0064 & 0.851 & 0.0040 & 0.537 \\
\hline $\operatorname{CAR}(-1,+1)$ & 103 & 0.0153 & $2.992^{* * *}$ & 62 & 0.0070 & 0.964 & 0.0083 & 0.934 \\
\hline $\operatorname{CAR}(-2,+2)$ & 103 & 0.0086 & 1.334 & 62 & -0.0010 & -0.098 & 0.0096 & 0.787 \\
\hline $\operatorname{CAR}(-5,+5)$ & 103 & 0.0079 & 0.970 & 62 & 0.0116 & 0.834 & -0.0037 & -0.265 \\
\hline
\end{tabular}

Table 5a: VA: High VA vs. Low VA

\begin{tabular}{|c|c|c|c|c|c|c|c|c|}
\hline \multirow{2}{*}{ Event window } & \multicolumn{3}{|c|}{ Low VA } & \multicolumn{3}{|c|}{ High VA } & \multicolumn{2}{|c|}{ VA effect } \\
\hline & $\mathrm{N}$ & Mean $\mathrm{CAR}_{\mathrm{L}}$ & t-Stat & $\mathrm{N}$ & Mean $\mathrm{CAR}_{\mathrm{H}}$ & t-Stat & $\mathrm{CAR}_{\mathrm{H}}-\mathrm{CAR}_{\mathrm{L}}$ & t-Value \\
\hline CAR $(-1,0)$ & 22 & -0.0034 & -0.381 & 143 & 0.0093 & $2.833^{* * *}$ & 0.0127 & 1.320 \\
\hline $\operatorname{CAR}(0,+1)$ & 22 & 0.0008 & 0.077 & 143 & 0.0095 & $2.304^{* *}$ & 0.0087 & 0.754 \\
\hline CAR $(-1,+1)$ & 22 & 0.0005 & 0.052 & 143 & 0.0131 & $2.934^{* * *}$ & 0.0126 & 1.210 \\
\hline $\operatorname{CAR}(-2,+2)$ & 22 & -0.0025 & -0.172 & 143 & 0.0056 & 0.939 & 0.0081 & 0.511 \\
\hline $\operatorname{CAR}(-5,+5)$ & 22 & -0.0099 & -0.435 & 143 & 0.0108 & 1.414 & 0.0207 & 0.860 \\
\hline
\end{tabular}

Note: VA=Voice and Accountability

${ }^{*} \mathrm{p}<0.1,{ }^{* *} \mathrm{p}<0.05,{ }^{* * *} \mathrm{p}<0.01$ 
Table 5b: PS: High PS vs. Low PS

\begin{tabular}{|c|c|c|c|c|c|c|c|c|}
\hline \multirow{2}{*}{ Event window } & \multicolumn{3}{|c|}{ Low PS } & \multicolumn{3}{|c|}{ High PS } & \multicolumn{2}{|c|}{ PS effect } \\
\hline & $\mathrm{N}$ & Mean $\mathrm{CAR}_{\mathrm{L}}$ & t-Stat & $\mathrm{N}$ & Mean $\mathrm{CAR}_{\mathrm{H}}$ & t-Stat & $\mathrm{CAR}_{\mathrm{H}^{-}}-\mathrm{CAR}_{\mathrm{L}}$ & t-Value \\
\hline $\operatorname{CAR}(-1,0)$ & 16 & 0.0056 & 0.888 & 149 & 0.0087 & $2.559^{* *}$ & 0.0031 & 0.433 \\
\hline $\operatorname{CAR}(0,+1)$ & 16 & 0.0124 & $1.806^{*}$ & 149 & 0.0085 & $1.995^{* *}$ & -0.0039 & -0.483 \\
\hline CAR $(-1,+1)$ & 16 & 0.0080 & 1.048 & 149 & 0.0126 & $2.758^{* * * *}$ & 0.0046 & 0.518 \\
\hline $\operatorname{CAR}(-2,+2)$ & 16 & 0.0076 & 0.817 & 149 & 0.0047 & 0.768 & -0.0029 & -0.260 \\
\hline $\operatorname{CAR}(-5,+5)$ & 16 & 0.0237 & 1.300 & 149 & 0.0078 & 0.993 & -0.0159 & -0.984 \\
\hline
\end{tabular}

Note: PS=Political Stability and Absence of Violence

${ }^{*} \mathrm{p}<0.1,{ }^{* *} \mathrm{p}<0.05,{ }^{* * *} \mathrm{p}<0.01$

Table 5c: GE: High GE vs. Low GE

\begin{tabular}{|c|c|c|c|c|c|c|c|c|}
\hline \multirow{2}{*}{ Event window } & \multicolumn{3}{|c|}{ Low GE } & \multicolumn{3}{|c|}{ High GE } & \multicolumn{2}{|c|}{ GE effect } \\
\hline & $\mathrm{N}$ & $\begin{array}{l}\text { Mean } \\
\text { CAR }_{\mathrm{L}}\end{array}$ & t-Stat & $\mathrm{N}$ & $\begin{array}{l}\text { Mean } \\
\text { CAR }_{\mathrm{H}}\end{array}$ & t-Stat & $\mathrm{CAR}_{\mathrm{H}}-\mathrm{CAR}_{\mathrm{L}}$ & t-Value \\
\hline CAR $(-1,0)$ & 25 & -0.0038 & -0.511 & 140 & 0.0096 & $2.870^{* * *}$ & 0.0134 & 1.647 \\
\hline $\operatorname{CAR}(0,+1)$ & 25 & 0.0141 & 1.691 & 140 & 0.0084 & $1.983^{* *}$ & -0.0057 & -0.610 \\
\hline CAR $(-1,+1)$ & 25 & 0.0062 & 0.655 & 140 & 0.0128 & $2.824^{* * *}$ & 0.0066 & 0.063 \\
\hline $\operatorname{CAR}(-2,+2)$ & 25 & -0.0018 & -0.121 & 140 & 0.0056 & 0.944 & 0.0074 & 0.470 \\
\hline $\operatorname{CAR}(-5,+5)$ & 25 & 0.0263 & 1.372 & 140 & 0.0076 & 0.979 & -0.0187 & -0.904 \\
\hline
\end{tabular}

Note: GE $=$ Government Effectiveness

${ }^{*} \mathrm{p}<0.1,{ }^{* *} \mathrm{p}<0.05,{ }^{* * *} \mathrm{p}<0.01$

Table 5d: RQ: High RQ vs. Low RQ

\begin{tabular}{|c|c|c|c|c|c|c|c|c|}
\hline \multirow{2}{*}{ Event window } & \multicolumn{3}{|c|}{ Low RQ } & \multicolumn{3}{|c|}{ High RQ } & \multicolumn{2}{|c|}{ RQ effect } \\
\hline & $\mathrm{N}$ & Mean $\mathrm{CAR}_{\mathrm{L}}$ & t-Stat & $\mathrm{N}$ & Mean $\mathrm{CAR}_{\mathrm{H}}$ & t-Stat & $\mathrm{CAR}_{\mathrm{H}^{-}}-\mathrm{CAR}_{\mathrm{L}}$ & t-Value \\
\hline CAR $(-1,0)$ & 13 & 0.0016 & 0.158 & 152 & 0.0090 & $2.728^{* * *}$ & 0.0074 & 0.716 \\
\hline $\operatorname{CAR}(0,+1)$ & 13 & 0.0124 & 1.293 & 152 & 0.0086 & $2.062^{* *}$ & -0.0038 & -0.364 \\
\hline CAR $(-1,+1)$ & 13 & 0.0093 & 0.913 & 152 & 0.0124 & $2.774^{* * *}$ & 0.0031 & 0.278 \\
\hline $\operatorname{CAR}(-2,+2)$ & 13 & -0.0018 & -0.116 & 152 & 0.0056 & 0.939 & 0.0074 & 0.436 \\
\hline CAR $(-5,+5)$ & 13 & 0.0362 & $1.807^{*}$ & 152 & 0.0070 & 0.910 & -0.0292 & -1.359 \\
\hline
\end{tabular}

Note: $\mathrm{RQ}=$ Regulator Quality

${ }^{*} \mathrm{p}<0.1,{ }^{* *} \mathrm{p}<0.05,{ }^{* * *} \mathrm{p}<0.01$ 
Table 5e: RL: High RL vs. Low RL

\begin{tabular}{|c|c|c|c|c|c|c|c|c|}
\hline \multirow{2}{*}{ Event window } & \multicolumn{3}{|c|}{ Low RL } & \multicolumn{3}{|c|}{ High RL } & \multicolumn{2}{|c|}{ RL effect } \\
\hline & $\mathrm{N}$ & Mean $\mathrm{CAR}_{\mathrm{L}}$ & t-Stat & $\mathrm{N}$ & Mean $\mathrm{CAR}_{\mathrm{H}}$ & t-Stat & $\mathrm{CAR}_{\mathrm{H}}-\mathrm{CAR}_{\mathrm{L}}$ & t-Value \\
\hline CAR $(-1,0)$ & 19 & 0.0004 & 0.066 & 146 & 0.0094 & $2.757^{* * *}$ & 0.0090 & 1.196 \\
\hline CAR $(0,+1)$ & 19 & 0.0108 & 1.591 & 146 & 0.0087 & $1.996^{* *}$ & -0.0021 & -0.261 \\
\hline CAR $(-1,+1)$ & 19 & 0.0057 & 0.756 & 146 & 0.0130 & $2.804^{* * *}$ & 0.0073 & 0.822 \\
\hline $\operatorname{CAR}(-2,+2)$ & 19 & -0.0005 & -0.047 & 146 & 0.0057 & 0.926 & 0.0062 & 0.477 \\
\hline CAR $(-5,+5)$ & 19 & 0.0170 & 1.087 & 146 & 0.0083 & 1.040 & -0.0087 & -0.495 \\
\hline
\end{tabular}

Note: RL=Rule of Law

${ }^{*} \mathrm{p}<0.1,{ }^{* *} \mathrm{p}<0.05,{ }^{* * *} \mathrm{p}<0.01$

Table 5f: CC: High CC vs. Low CC

\begin{tabular}{|c|c|c|c|c|c|c|c|c|}
\hline \multirow{2}{*}{ Event window } & \multicolumn{3}{|c|}{ Low CC } & \multicolumn{3}{|c|}{ High CC } & \multicolumn{2}{|c|}{ CC effect } \\
\hline & $\mathrm{N}$ & Mean $\mathrm{CAR}_{\mathrm{L}}$ & t-Stat & $\mathrm{N}$ & Mean $\mathrm{CAR}_{\mathrm{H}}$ & t-Stat & $\begin{array}{c}\mathrm{CAR}_{\mathrm{H}}-\mathrm{CAR} \\
\mathrm{L}\end{array}$ & t-Value \\
\hline CAR $(-1,0)$ & 21 & 0.0019 & 0.309 & 144 & 0.0093 & $2.698^{* * *}$ & 0.0074 & 1.020 \\
\hline $\operatorname{CAR}(0,+1)$ & 21 & 0.0097 & 1.544 & 144 & 0.0088 & $1.999^{* *}$ & -0.0009 & -0.117 \\
\hline $\operatorname{CAR}(-1,+1)$ & 21 & 0.0083 & 1.101 & 144 & 0.0128 & $2.719^{* * *}$ & 0.0045 & 0.508 \\
\hline CAR $(-2,+2)$ & 21 & 0.0017 & 0.163 & 144 & 0.0054 & 0.876 & 0.0037 & 0.300 \\
\hline $\operatorname{CAR}(-5,+5)$ & 21 & 0.0197 & 1.323 & 144 & 0.0078 & 0.966 & -0.0119 & -0.702 \\
\hline
\end{tabular}

Note: $\mathrm{CC}=$ Control of Corruption

${ }_{\mathrm{p}}^{*}<0.1,{ }^{* *} \mathrm{p}<0.05,{ }^{* * *} \mathrm{p}<0.01$

Table 6: Ownership: SOE acquirer vs. private acquirers

\begin{tabular}{|c|c|c|c|c|c|c|c|c|}
\hline \multirow{2}{*}{$\begin{array}{c}\text { Event } \\
\text { window }\end{array}$} & \multicolumn{3}{|c|}{ SOE } & \multicolumn{3}{|c|}{ Private } & \multicolumn{2}{|c|}{$\begin{array}{c}\text { Ownership status } \\
\text { effect }\end{array}$} \\
\hline & $\mathrm{N}$ & $\begin{array}{l}\text { Mean } \\
\text { CAR }_{S}\end{array}$ & t-Stat & $\mathrm{N}$ & $\begin{array}{l}\text { Mean } \\
\text { CAR }_{P}\end{array}$ & t-Stat & $\begin{array}{c}\mathrm{CAR}_{\mathrm{P}}-\mathrm{C} \\
\mathrm{AR}_{\mathrm{S}}\end{array}$ & $\mathrm{t}$-Value \\
\hline CAR $(-1,0)$ & 69 & 0.0019 & 0.582 & 96 & 0.0131 & $2.722^{* * *}$ & 0.0112 & $1.934^{*}$ \\
\hline $\operatorname{CAR}(0,+1)$ & 69 & 0.0035 & 1.079 & 96 & 0.0128 & $2.03^{* *}$ & 0.0093 & 1.311 \\
\hline $\operatorname{CAR}(-1,+1)$ & 69 & 0.0030 & 0.766 & 96 & 0.0188 & $2.852^{* * *}$ & 0.0158 & $2.066^{* *}$ \\
\hline $\operatorname{CAR}(-2,+2)$ & 69 & -0.0037 & -0.628 & 96 & 0.0112 & 1.298 & 0.0149 & 1.433 \\
\hline CAR $(-5,+5)$ & 69 & 0.0146 & 1.572 & 96 & 0.0055 & 0.518 & -0.0091 & -0.644 \\
\hline
\end{tabular}

